\title{
FAMA FRENCH 5 FACTOR MODEL VERSUS ALTERNATIVE FAMA FRENCH 5 FACTOR MODEL: EVIDENCE FROM SELECTED ISLAMIC COUNTRIES
}

\author{
Nevin ÖZER ${ }^{a}$ \\ (D) Ali ÖZERc
}

\begin{abstract}
In this study, the validity of the five-factor model in developing and underdeveloped countries was investigated in 2012-2020, as well as the validity of the model to be created by using the inflation rate instead of the risk-free interest rate, and the answers to the questions of its comparison with the original model. In seeking an answer to this question, Pakistan, Malaysia, Indonesia and Turkey were selected as the countries with interest-sensitive investors. In the study, the Kuala Lumpur Composite Index (KLCI) for Malaysia, the Jakarta Islamic Index (JKII) for Indonesia, the Karachi Meezan Index (KMI) for Pakistan and the Participation Index (KATLM) for Turkey were selected for the study and analysis was carried out on the top 30 companies in the index.

In terms of the created portfolios, it is seen that different portfolios are effective in terms of the highest excess return in selected countries. In fact, it has been observed that the portfolio with the highest extreme return in a country has the lowest return in the other country. It can only be said that the excessive return of small firms is greater than that of large firms. Looking at the fluctuation of excess returns, it is seen that Pakistan and Indonesia markets are risky, while Malaysia is the least risky. As a result of the analysis, evidence has been obtained that the original model has little advantage over the inflation model and that they are very close to each other. It can be said that the FF5F model is also effective in developing and underdeveloped country markets, and interest-sensitive investors can model using the inflation rate.
\end{abstract}

a Dr. Öğr. Üyesi, Düzce University, nevinozer@duzce.edu.tr

b Prof. Dr., Düzce University, mehmetakifoncu@duzce.edu.tr

c Doç. Dr., Düzce University, aliozer@duzce.edu.tr

d Doç. Dr., Düzce University, istemicomlekci@duzce.edu.tr 
Keywords: Islamic Economy, Finance, CAPM, Fama-French 5 Factor, Interest Rate, Inflation.

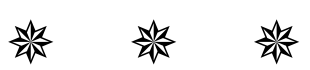

\section{FAMA FRENCH 5 FAKTÖR MODELINE KARŞI ALTERNATIF FAMA FRENCH 5} FAKTÖR MODELİ: SEÇİLMIŞ İSLAM ÜLKELERİ UYGULAMASI

Bu çalışmada, 2012-2020 yıllarında hem beş faktörlü modelin gelişmekte olan ve az gelişmiş ülkelerde geçerliğine cevap aranırken, bir yandan da risksiz faiz oranı yerine enflasyon oranı kullanılarak oluşturulacak modelin geçerliliği ve orijinal model ile karşılaştırılması sorularına cevap aranmıştır. Bu soruya cevap aranırken faiz hassasiyeti olan yatırımcıların olabileceği ülkeler olarak Pakistan, Malezya, Endonezya ve Türkiye seçilmiştir. Çalışmada Malezya için Kuala Lumpur Bileşik Endeksi (KLCI), Endenozya için Jakarta İslami Endeksi (JKII), Pakistan için Karachi Meezan Endeksi (KMI) ve Türkiye için ise Katılım Endeksi (KATLM) seçilmiş ve endeksteki en büyük 30 firma üzerinden analiz gerçekleştirilmiştir.

Oluşturulan porföyler açısından, seçilen ülkelerde en yüksek aşırı getiri açısından farklı portföylerin etkin olduğu görülmektedir. Hatta bir ülkede en yüksek aşırı getiriye sahip olan portföyün, diğer ülkede en düşük getiriye sahip olduğu görülmüştür. Sadece küçük firmaların aşırı getirisinin, büyük firmalardan fazla olduğu söylenebilir. Aşırı getirilerin dalgalanmasına bakıldığında Pakistan ve Endonezya piyasalarının riskli olduğu, Malezya'nın ise en az riskli olduğu görülmektedir. Yapılan analizler sonucunda, orijinal modelin enflasyonlu modelden küçük üstünlüğünün bulunduğu ve birbirilerine çok yakın olduğuna dair kanıtlar elde edilmiştir. FF5F modelinin gelişmekte olan ve az gelişmiş ülke piyasalarında da etkin olduğu ve faiz hassasiyeti olan yatırımcıların enflasyon oranını kullanarak modelleme yapabileceği söylenebilir...

[Türkçe Genişö̈z, makalenin sonunda yer almaktadır.]

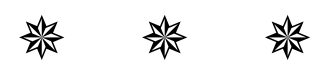

\section{Introduction}

Islamic financial assets have an increasing prominence day by day. Islamic financial assets, which had a size of $\$ 1.76$ billion in 2012 , reached $\$$ 2.8 billion in $2019.69 \%$ of Islamic financial assets, which is expected to reach approximately $\$ 3.7$ billion in 2024, are comprised of Islamic Banks (ICD, 2020).

Islamic finance is shaped according to Islamic principles. It cannot provide financing for an activity prohibited by Islamic law (alcohol, gambling, pork, etc.), or cannot put out to loan at interest (only charitable 
loans are allowed), and when financing is provided within the scope of profit and loss sharing, it is shared according to capital contribution / ownership (Hanif, 2011). The most important issue regarding the concept of Islamic finance based on Islamic principles is the principle of interest-free stated in Aya 275 of the Sura Al-Baqarah in Quran (Allah has permitted trading and forbidden Ribâ).

On the other hand, models developed on asset pricing theory generally focused on the relationship between risk and return. Capital asset pricing model (CAPM) propounded by Sharpe (1964), Lintner (1965) and Mossin (1966), three-factor asset pricing model asserted by Fama and French $(1993,2015)$, and five-factor asset pricing model have been developed based upon the risk-free rate of return. In the literature, it is obviously seen that government bonds as the risk-free rate of return have been reviewed. In this concept, it is inevitable to advance an interest-free asset pricing model, while practising of asset pricing model by investors of Islamic financial assets planning to act by the principle of interest-free.

The growth and development of Islamic finance is a topic discussed by academics (Yücel and Köseoğlu, 2020). On the other hand, the fact that the Islamic economy was built on the principle of interest-free has led to the development of various models for the advancement of the interest-free financial asset pricing model. Tomkins and Karim (1987) suggested a model in which they did not work in risk-free rate of return, whereas Ashker (1987) asserted that instead of a risk-free rate of return, rate of zakat (rate of zakat/ (1-rate of zakat)) may be used. Shaikh (2009) suggested that nominal gross domestic product might be used instead of a risk-free rate of return. Hanif (2011) also advocated that Islamic financial asset pricing models predicated on a basket organized by currencies, selected goods or Consumer Price Index (CPI), and Wholesale Price Index (WPI) could be developed. Under the Islamic financial system, the investor's compensation in the economy at least equal to the inflation rate is on the agenda. For this reason, instead of the risk-free interest rate in the Fama French 5 factor model, the inflation rate was considered and the results were compared with the risk-free interest rate.

The main purpose of this study is to practice the validity of the Fama \& French Five-Factor Asset Pricing Model on Islamic Finance. In line with this, an interest-free model has been developed by using inflation value instead of risk-free interest rate approved in Fama \& French Five-Factor Asset Pricing Model. Then, the results of the Fama \& French Five-Factor Asset 
Pricing Model and Islamic Fama \& French Five-Factor Asset Pricing Model were compared.

\section{A. Literature}

The Capital Asset Pricing Model (CAPM), which emerged on the basis of the efficient markets hypothesis, provides the opportunity to be applied to both a financial asset and a portfolio. It examines the relationship between the CAPM model and the risk and return of the investment (Merton, 1973: 867). It uses market beta to measure systematic risk. It practices upon price differences applied in various markets by differentiating the market with the Arbitrage Pricing Theory (APT) developed as an alternative to CAPM by Ross (1976:345). In the model of APT, variances of return have been clarified by systematic risk. In his study, Banz (1981) advocated that not only systematic risk is sufficient, but also variable of firm size is also effective to clarify return. Practicing upon common stock in NYSE, the author detected that small firms yield more returns than large firms and this influence has existed for many years. Moreover, he advocated that CAPM has been descripted inaccurately. Basu (1983) tried to explain returns of NYSE stocks by insetting priceearnings ratio to the model. The author found that stocks that have high price-earnings ratio yield more return than stocks that have low priceearnings ratio. Rosenberg et al. (1985) in their study examining NYSE added the market to book value ratio. Debont and Thaler (1985) explained the excessive movements in stock prices with the hypothesis of overreactivity in their work with CRSP monthly return data. Researchers also emphasize that CAPM does not explain the change in returns by the result of an event or news that affect stocks. Stoll and Whaley (1990) used transaction costs and a high degree of leverage to explain the changes in S \& P500 and MM futures index returns. Bhandari (1988) tried to clarify changes in returns of stocks with risk and size by adding leverage rate to the model. He found that there were positive relationships between returns and risk, and also size and leverage rate.

Fama and French (1992), tried to explain returns of stock by adding on short and long term past returns, and rate of cash flows besides determinants added by researchers. In this study, panel data analysis were conducted with NYSE, AMEX and NASDAQ data between 1962-1989. As a result of the study, although the CAPM reached consistent results, it was found that it was not explanatory enough, and there was a strong relationship between firm size and market to book value ratio and stock 
In a similar study, Fama and French (1993) applied the FF3 model on NYSE and NASD stocks and found that small-sized companies with high market to book value ratios provided higher returns due to their higher risk level. In addition to their previous studies, Fama and French (1995) examined the relationship between stock size and earnings with the market to book value ratio. They applied the FF3 model and regression analysis by grouping them with NYSE, AMEX and NASDAQ stocks according to size and market to book value ratio between 1963-1992. As a result of the study, they found that size and market to book value ratio are effective in stock earnings and the stocks of small-scale and high market to book value ratio companies get more earnings.

Fama and French (2015), in their study regarding stock returns of NYSE, AMEX and NASDAQ between 1963-2013, extended the model by adding the profitability and investment factors as a solution to matters encountered due to anomalies of three-factor model FF. They applied panel data analysis by using the FF3 and FF5 asset pricing model. They also found that model FF5 that emerged by adding profitability and investment factors to the model FF3 performed measures more sensitive.

Cakici (2015) created three different sized portfolios with groups of 25 in 23 developed country stock exchanges during the period 1992-2014, and analyzed the returns with the model FF5 globally and regionally. They have found similar results in the US, European and Global stock markets. They emphasized that the value factor maintains its importance in all markets except the USA, with the inclusion of gross profitability and investment variables. They also found that regional models give better results than global models. Chiah et al. (2016), in the period 1982-2013 and Heaney et al. (2016), in the period 1993-2012 found that the model was successful in their studies where they applied the model FF5 on stock returns in Australia. Yang et al. (2017), with the aim of analyzing service sector in USA, compared three types of 5 factors used on the point of Global 5 factors and North America 5 factors with monthly returns of 1990-2017 term. Likewise, Zhou et al. (2016) found in the study that the model FF5 was also successful in explaining in the USA.

Erdinç (2018), in his study applying in BIST between 2000-2017 and examining model FF3 and FF5, found that FF5 factor clarified changes in stocks better than model FF3. Coşkun and Torun (2021) analyzed stock exchange securities by using regression analysis on BIST100 between 20092018 with models FF3 and FF5. As a result of the study, it was found that 
both two models were practicable in BIST and model FF3 showed better performance.

\section{B. Data and Methodology}

In this study, the original model of the Fama-French 5-factor model with the risk-free interest rate in Islamic countries and the Fama-French 5factor model, which were created by using the inflation rate instead of the interest rate in 2012-2019, have been analyzed comparatively. In order to eliminate the negative effects of the Covid-19 pandemic on the financial statements of the businesses and the inflation rates of the countries, 2020 data have not been included in the scope of the research.

According to the financial information and awareness indicators (ICD, 2020) of the Islamic Finance Development Report, the top three countries are Malaysia, Indonesia and Pakistan. Within the scope of the study, these three countries and Turkey, a country where Islamic finance has developed rapidly, are discussed. In this study for Malaysia Kuala Lumpur Composite Index (KLCI), for Indonesia Jakarta Islamic Index (JKII), for Pakistan Karachi Meezan Index (KMI), and for Turkey, Participation Index (KATLM) have been chosen for the study and analysis has been conducted by way of biggest 30 firms in the index. The data of the companies included in the study have been obtained from Thomson Reuters Eikon database.

Factors required to test the model in the study are SMB (Small Minus Big- Size Factor), HLM (High Minus Low-Value Factor, Market to Book Value Ratio), RMW (Robust Minus Weak-Profitability Factor) and CMA (Conservative Minus Aggressive- Investment Factor) four factors of the model and $(R m-R \mathrm{i})$ that are market premium factor, and inflation rate factor ( $R m-R$ inf $)$ that has been used instead of risk-free interest rate in this study. A separate data set has been created for the stocks selected from the countries and countries used in the study and then combined for the formation of factors and portfolios. The size factor is obtained by calculating the market values of each firm at the end of June of the $t$ year. After calculating the market value for June, firms are divided into two groups as large and small. The portfolios are recalculated and updated each year from July of year $t$ to the end of June of year $t+1$. While calculating the value factor, market to book value ratio has been used. While calculating the market to book value, it has been calculated by considering the price of the stock in June and the paid-in capital value at the end of the period $t-1$. Then the results obtained have been listed in descending order. Later, firms are divided into three groups according to their B / M values as lower 30\%, middle $40 \%$ and 
upper $30 \%$. These groups are named as high, medium and low. For this factor, portfolios are updated annually. The profitability factor is calculated by dividing the $\mathrm{t}-1$ period end value of the operating profitability by the year t-1 equity value. In establishing the investment factor, the difference between the year t- 1 and $\mathrm{t}-2$ of the total assets have been taken and proportioned to the year $\mathrm{t}-2$. Profitability and investment factors, as in the value factor, are ranked in descending order and divided into three groups. Table 1 shows the portfolios obtained from these factors and intersections.

Table 1: Fama-French Portfolio Construction and Fama-French Factors

\begin{tabular}{|c|c|c|c|c|c|c|c|}
\hline & & \multicolumn{2}{|c|}{$\mathrm{B} / \mathrm{M}$} & \multicolumn{2}{|c|}{ Profitability } & \multicolumn{2}{|c|}{ Investment } \\
\hline & & $\mathrm{H}$ & $\mathrm{L}$ & W & $\mathrm{R}$ & $\mathrm{A}$ & $\mathrm{C}$ \\
\hline \multirow{2}{*}{ Size } & $\mathrm{B}$ & $\mathrm{BH}$ & $\mathrm{BL}$ & BW & $\mathrm{BR}$ & BA & $\mathrm{BC}$ \\
\hline & $\mathrm{S}$ & SH & SL & SW & SR & SA & $\mathrm{SC}$ \\
\hline \multirow{2}{*}{\multicolumn{2}{|c|}{$\begin{array}{l}2 \times 2 \text { sorts on } \\
\text { Size and } \mathrm{B} / \mathrm{M} \text {, or } \\
\text { Size and } \mathrm{OP} \text {, or }\end{array}$}} & \multicolumn{6}{|c|}{$\begin{array}{l}\mathrm{S} M B=(S H+S L+S R+S W+S C+S A) / 6-(B H+B L+B R+B W \\
+B C+B A) / 6\end{array}$} \\
\hline & & \multicolumn{6}{|c|}{$H M L=(S H+B H) / 2-(S L+B L) / 2$} \\
\hline \multicolumn{2}{|c|}{$\begin{array}{l}\text { Size and INV } \\
\text { Size: Median }\end{array}$} & \multirow{2}{*}{\multicolumn{6}{|c|}{$R M W=(S R+B R) / 2-(S W+B W) / 2$}} \\
\hline \multicolumn{2}{|c|}{$\begin{array}{l}\text { B/M: Median } \\
\text { OP: Median }\end{array}$} & & & & & & \\
\hline INV: & dian & \multicolumn{6}{|c|}{$C M A=(S C+B C) / 2-(S A+B A) / 2$} \\
\hline
\end{tabular}

Note: B: Big, S: Small, H: High, L: Low, W: Weak, R: Robust, A: Aggressive, C: Conservative

Since the largest 30 companies from each country were included, factor formation has been made according to $2 \times 2$. Table 1 shows the way in which size, value, profitability and investment factors are calculated and the intersection portfolios used in the study. BH, BL, SH and SL portfolios have been obtained from the size-value intersection. BW, BR, SW and SR portfolios have been obtained from the size-profitability intersection. BA, BC, SA and SC portfolios have been obtained from the intersection of size-investment. The middle groups of factors are not needed in factor formation according to $2 \times 2$, so they are not shown in the table. The size factor (SMB) is calculated by taking the difference between the average of portfolios consisting of the intersection of small firms, B / M ratio, profitability and investment factors, and the average of portfolios consisting of the intersection of large firms with B / M ratio, profitability and investment factors. The value factor (HML) is calculated by taking the difference between the average of firms with high $\mathrm{B}$ 
/ M ratio and the average of firms with low B / M ratio. Profitability factor (RMW) is calculated by taking the difference between the average of firms with strong profitability and the average of firms with weak profitability. While creating the investment factor (CMA), it is calculated by taking the difference between companies with conservative and aggressive investment conceptions.

The econometric representation of the five-factor model proposed by Fama and French (2015) is as in model-1, furthermore, model-2 shows the model in which inflation is used instead of the risk-free interest rate;

$$
\begin{aligned}
& \mathrm{R}_{\mathrm{t}}-\mathrm{R}_{\mathrm{f}(\mathrm{t})}=\alpha+\mathrm{b}\left[\mathrm{R}_{\mathrm{M}(\mathrm{t})}-\mathrm{R}_{\mathrm{F}(\mathrm{t})}\right]+\mathrm{sSMB}_{(\mathrm{t})}+\mathrm{hHML}_{(\mathrm{t})}+\mathrm{rRMW}_{(\mathrm{t})}+\mathrm{cCMA}_{(\mathrm{t})} \\
& +\mathrm{e}_{(\mathrm{t})} \\
& \mathrm{R}_{\mathrm{t}}=\text { Return of equity or porfolio } \\
& \mathrm{R}_{\mathrm{f}(\mathrm{t})}=\text { Risk-free return } \\
& \mathrm{R}_{\mathrm{M}(\mathrm{t})}=\text { Market Return } \\
& \mathrm{R}_{\mathrm{t}}-\mathrm{R}_{\mathrm{INF}(\mathrm{t})}=\alpha+\mathrm{b}\left[\mathrm{R}_{\mathrm{M}(\mathrm{t})}-\mathrm{R}_{\mathrm{F}(\mathrm{t})}\right]+\operatorname{sSMB}_{(\mathrm{t})}+\mathrm{hHML}_{(\mathrm{t})}+\mathrm{rRMW}_{(\mathrm{t})}+\mathrm{cCMA}_{(\mathrm{t})} \\
& +\mathrm{e}_{(\mathrm{t})} \quad \mathrm{R}_{\mathrm{INF}(\mathrm{t})}=\text { Inflation }
\end{aligned}
$$

$\alpha$, constant term; b, s, h, r, c are factor coefficients expressing the slope of multiple regressions between Rm-Rf, SMB, HML, RMW and CMA, and e ( $t$ ) is the zero mean error term. If the coefficients $b, s, h, r, c$ obtained in the study reflect the real values, the coefficient $\alpha$ must be equal to zero for all stocks and portfolios. Therefore, theoretically a good factor model should have a constant coefficient that is not statistically different from zero. The GRS test statistic, developed by Gibbons, Ross, and Shanken (1989), is often recommended in studies to determine whether alpha coefficient values differ significantly from zero. (Gibbons et al., 1989, p. 1124).

\section{Findings}

Before testing the models to be used in the study, basic information about the data has been presented and the unit roots of the obtained factors have been examined in terms of stationarity.

Table 2: Average Monthly Excess Returns and Standard Deviations (\%)

\begin{tabular}{|l|l|l|l|l|l|}
\hline \multicolumn{2}{|l|}{ Pakistan } & \multicolumn{2}{|l|}{ Indonesia } \\
\hline & $\begin{array}{l}\text { Excess } \\
\text { Return }\end{array}$ & $\begin{array}{l}\text { Standard } \\
\text { Deviation }\end{array}$ & & $\begin{array}{l}\text { Excess } \\
\text { Return }\end{array}$ & Standard Deviation \\
\hline SL & 1,036 & 7,757 & SL & $-0,011$ & 6,458 \\
\hline
\end{tabular}


Fama French 5 Factor Model Versus Alternative Fama French 5 Factor Model

\begin{tabular}{|c|c|c|c|c|c|}
\hline SH & 1,476 & 8,752 & SH & $-0,249$ & 7,544 \\
\hline BL & 0,752 & 8,878 & BL & 0,612 & 7,275 \\
\hline BH & 0,647 & 10,208 & BH & $-0,217$ & 8,285 \\
\hline SR & 0,420 & 6,591 & SR & 0,588 & 10,780 \\
\hline SW & 1,594 & 8,703 & SW & $-0,243$ & 6,025 \\
\hline BR & 2,844 & 10,400 & BR & $-0,833$ & 7,007 \\
\hline BW & 1,563 & 9,770 & BW & $-0,197$ & 5,969 \\
\hline SC & 2,009 & 8,006 & SC & 0,449 & 12,602 \\
\hline SA & 1,029 & 8,314 & SA & 0,912 & 7,872 \\
\hline BC & 1,269 & 7,926 & BC & 0,390 & 8,282 \\
\hline BA & 1,350 & 9,764 & BA & 1,198 & 13,279 \\
\hline \multicolumn{3}{|c|}{ Malaysia } & \multicolumn{3}{|c|}{ Turkey } \\
\hline & $\begin{array}{l}\text { Excess } \\
\text { Return }\end{array}$ & $\begin{array}{l}\text { Standard } \\
\text { Deviation }\end{array}$ & & $\begin{array}{l}\text { Excess } \\
\text { Return }\end{array}$ & Standard Deviation \\
\hline SL & 0,125 & 3,186 & SL & 2,099 & 1,175 \\
\hline SH & 0,959 & 3,652 & SH & 1,164 & 1,273 \\
\hline BL & $-0,290$ & 3,106 & BL & 0,470 & 6,700 \\
\hline BH & 0,721 & 4,043 & BH & 0,982 & 5,802 \\
\hline SR & 0,136 & 3,011 & SR & 0,522 & 6,380 \\
\hline SW & 0,260 & 3,318 & SW & 0,871 & 6,895 \\
\hline BR & 0,938 & 2,676 & BR & 0,653 & 6,148 \\
\hline BW & 0,154 & 3,132 & BW & $-0,152$ & 6,019 \\
\hline SC & 0,353 & 3,323 & SC & 0,782 & 6,321 \\
\hline SA & $-0,338$ & 3,094 & SA & 1,008 & 6,470 \\
\hline BC & $-0,475$ & 3,598 & BC & 0,814 & 6,701 \\
\hline BA & 0,204 & 2,704 & BA & 0,449 & 5,059 \\
\hline
\end{tabular}

Table 2 shows the statistics about the parts of the intersection portfolios used in the study that exceeds the market return on average. While the monthly excess return of the portfolio formed by large and profitable companies in Pakistan is the highest, small and thrifty companies in terms of investment take second place. The lowest excess return is seen in small and highly profitable firms. Looking at Indonesia, it is seen that the highest excess return is in large and investment-aggressive firms, and the second is in small and investment-aggressive firms. It can be said that the average return 
exceeding the market return of companies with an aggressive investment approach in Indonesia is the highest. The lowest-return portfolio has been seen in small firms with a high B / M ratio. While small and high B / M ratio companies have the highest excess return in Malaysia, there are large and profitable companies in second place. The lowest return has been seen in large and conservative firms in terms of investment. Finally, when looking at Turkey's highest excess return on small and B / M ratio in the low company and the second is small and B / M ratio seems to be in high company. It can be said that firms that have small market value have higher excess returns. On the other hand, the lowest excess return is seen to be in large companies with low profitability. It is seen that different portfolios are effective in terms of the highest excess return in countries. In fact, it has been observed that the portfolio with the highest excess return in a country has the lowest return in the other country. It can only be said that the excess returns of small firms are greater than large firms. Looking at the fluctuation in excess returns, it is seen that Pakistan and Indonesia markets are risky, while Malaysia is the least risky. After the statistics about the portfolios created in the study, the correlation relationship of the factors to be used in the models created by the portfolios has been examined.

Table 3: Correlation Matrix

\begin{tabular}{|c|c|c|c|c|c|c|c|c|c|c|}
\hline & \multicolumn{5}{|c|}{ PAKISTAN } & \multicolumn{5}{|c|}{ INDONESIA } \\
\hline & RMRF & CMA & HML & RMW & SMB & RMRF & CMA & HML & RMW & SMB \\
\hline RMRF & 1,000 & & & & & 1,000 & & & & \\
\hline CMA & 0,204 & 1,000 & & & & 0,088 & 1,000 & & & \\
\hline HML & $-0,175$ & $-0,258$ & 1,000 & & & 0,146 & 0,041 & 1,000 & & \\
\hline RMW & $-0,427$ & 0,157 & 0,005 & 1,000 & & 0,031 & 0,193 & $-0,213$ & 1,000 & \\
\hline \multirow[t]{2}{*}{ SMB } & 0,015 & $-0,002$ & 0,360 & 0,126 & 1,000 & 0,254 & 0,396 & 0,415 & 0,091 & 1,000 \\
\hline & RMINF & CMA & HML & RMW & SMB & RMINF & CMA & HML & RMW & SMB \\
\hline RMINF & 1,000 & & & & & 1,000 & & & & \\
\hline CMA & 0,205 & 1,000 & & & & 0,088 & 1,000 & & & \\
\hline HML & $-0,175$ & $-0,258$ & 1,000 & & & 0,146 & 0,041 & 1,000 & & \\
\hline RMW & $-0,424$ & 0,157 & 0,005 & 1,000 & & 0,029 & 0,193 & $-0,213$ & 1,000 & \\
\hline SMB & 0,013 & $-0,002$ & 0,360 & 0,126 & 1,000 & 0,253 & 0,396 & 0,415 & 0,091 & 1,000 \\
\hline
\end{tabular}


Fama French 5 Factor Model Versus Alternative Fama French 5 Factor Model

\begin{tabular}{|c|c|c|c|c|c|c|c|c|c|c|}
\hline & \multicolumn{5}{|c|}{ MALAYSIA } & \multicolumn{5}{|c|}{ TURKEY } \\
\hline & RMRF & CMA & HML & RMW & SMB & RMRF & CMA & HML & RMW & SMB \\
\hline RMRF & 1,000 & & & & & 1,000 & & & & \\
\hline CMA & 0,314 & 1,000 & & & & $-0,005$ & 1,000 & & & \\
\hline HML & 0,053 & 0,041 & 1,000 & & & $-0,065$ & $-0,322$ & 1,000 & & \\
\hline RMW & $-0,061$ & $-0,008$ & 0,253 & 1,000 & & 0,007 & 0,248 & $-0,271$ & 1,000 & \\
\hline \multirow[t]{2}{*}{ SMB } & 0,096 & 0,022 & 0,326 & 0,448 & 1,000 & $-0,086$ & $-0,200$ & 0,157 & $-0,210$ & 1,000 \\
\hline & RMINF & CMA & HML & RMW & SMB & RMINF & CMA & HML & RMW & SMB \\
\hline RMINF & 1,000 & & & & & 1,000 & & & & \\
\hline CMA & 0,309 & 1,000 & & & & $-0,006$ & 1,000 & & & \\
\hline HML & 0,055 & 0,041 & 1,000 & & & $-0,059$ & $-0,322$ & 1,000 & & \\
\hline RMW & $-0,060$ & $-0,008$ & 0,253 & 1,000 & & 0,004 & 0,248 & $-0,271$ & 1,000 & \\
\hline SMB & 0,097 & 0,022 & 0,326 & 0,448 & 1,000 & $-0,086$ & $-0,200$ & 0,157 & $-0,210$ & 1,000 \\
\hline
\end{tabular}

Regarding Table 3, the highest correlation in Pakistan is between HML and SMB by $36 \%$, in Indonesia it is between HML and SMB by $41,5 \%$, it is also in Malaysia between SMB and RMW by 44,8\%, and in Turkey the highest correlation is seen between HML and CMA by $32,2 \%$. It is seen that the correlation relationship between the factors created for the countries used in the study is below $45 \%$. Therefore, there does not appear to be a multilinearity problem in terms of regression analysis. In all countries, it has been observed that the risk-free interest rate used in the study and the inflation rate are close to each other and in the same direction. Before proceeding to the regression analysis, the stationarity of the factors used in the study has been examined lastly. While examining the stationarity of the series, the Augmented Dickey-Fuller (ADF) unit root test (Dickey and Fuller, 1981) and the Phillips-Perron (PP) unit root test (Phillips and Perron, 1988) were used.

Table 4: Unit Root Tests

\begin{tabular}{|c|c|c|c|c|}
\hline & \multicolumn{2}{|c|}{ PAKISTAN } & \multicolumn{2}{|c|}{ INDONESIA } \\
\hline & ADF & PP & ADF & PP \\
\hline RMENF & $-11,48094^{*}$ & $-11,33554^{*}$ & $-9,953048^{*}$ & $-10,02475^{*}$ \\
\hline RMRF & $-11,42729^{*}$ & $-11,28722^{*}$ & $-9,952929 *$ & $-10,02525^{*}$ \\
\hline CMA & $-9,767305^{*}$ & $-9,767599 *$ & $-11,01596^{*}$ & $-10,93525^{*}$ \\
\hline
\end{tabular}


Nevin ÖZER, Mehmet Akif ÖNCÜ \& Ali ÖZER

\begin{tabular}{|l|l|l|l|l|l|}
\hline HML & $-8,157976^{*}$ & $-8,261705^{*}$ & & $-9,990382^{*}$ & $-9,990741^{*}$ \\
\hline RMW & $-7,221668^{*}$ & $-7,221668^{*}$ & & $-12,21333^{*}$ & $-12,19652^{*}$ \\
\hline SMB & $-10,52529^{*}$ & $-10,52289^{*}$ & & $-11,67837^{*}$ & $-11,69345^{*}$ \\
\hline & MALAYSIA & ADF & & TURKEY & ADF \\
\hline RMENF & $-10,80937^{*}$ & $-11,36910^{*}$ & $-10,05164^{*}$ & PP \\
\hline RMRF & $-10,73094^{*}$ & $-11,19046^{*}$ & & $-10,29729^{*}$ \\
\hline CMA & $-7,779462^{*}$ & $-7,802283^{*}$ & & $-10,09567^{*}$ & $-10,50269^{*}$ \\
\hline HML & $-9,555595^{*}$ & $-9,570519^{*}$ & & $-8,64292^{*}$ & $-10,63729^{*}$ \\
\hline RMW & $-9,396933^{*}$ & $-9,396933^{*}$ & & $-9,712000^{*}$ & $-8,353929^{*}$ \\
\hline SMB & $-8,693862^{*}$ & $-8,673675^{*}$ & $-10,44401^{*}$ & $-10,43753^{*}$ \\
\hline
\end{tabular}

Note: * denote statistical significance at the $1 \%$ level.

In Table 4, the stationarity of the factors used in the study was investigated by both Augmented Dickey Fuller (ADF) and Philips-Perron (PP) unit root tests. As a result of both tests, it was determined that all factors were stationary at $1 \%$ for all countries.

In their study, Fama and French (2015) found that the HML factor was close to zero in the formation of $2 * 3$ factors, as a result of the regression in which the formed factors has been made as independent variables. In the formation of a $2 * 2$ factor, it took the value 0 . It has begun to be discussed whether the HML factor is insufficient to explain the average returns. In their study, Fama and French (2017) revealed that HML is not unnecessary when it includes different countries from the USA. In this study, whether the factors created according to the $2 * 2$ factor formation are different from zero in explaining the average returns are examined both in terms of countries used in the study and in terms of the model in which inflation is used.

Four Factor Regression Analysis Results are presented in Table 5 as an appendix. (Table 5a-Pakistan, Table 5b-Indonesia, Table 5c-Malaysia, Table $5 \mathrm{~d}$-Turkey). When Table 5 is examined, it is found that the factors used are non-zero in both the original Fama-French 5 factor (FF5F) model and the inflation model for all countries. Thus, it can be said that the average returns of all the factors used are appropriate in the explanation. It has been concluded that the HML factor is not an unnecessary factor for the countries used in the study. In addition, when compared the original model FF5F with the inflation model, it is seen that the average returns in both models are very close to each other in explanation. Looking at the coefficients and $\mathrm{R}^{2}$ values, 
it is seen that the original model can explain better with a little difference. When Table $5 \mathrm{a}$ is examined for Pakistan, the average $\mathrm{R}^{2}$ for the original model is $32.78 \%$, while the average $\mathrm{R}^{2}$ for the inflationary model is $32.58 \%$. When Table $5 \mathrm{~b}$ is examined for Indonesia, the average $\mathrm{R}^{2}$ is $36.88 \%$ in the original model, while the average $\mathrm{R}^{2}$ in the inflation model is $36.04 \%$. When Table $5 \mathrm{c}$ is examined for Malaysia, the average $\mathrm{R}^{2}$ for the original model is $26.14 \%$, while the average $\mathrm{R}^{2}$ for the inflation model is $26.12 \%$. When Table $5 \mathrm{~d}$ is examined, While the average $\mathrm{R}^{2}$ for Turkey is $14.14 \%$ in the original model, average $\mathrm{R}^{2}$ in inflation model is $14.12 \%$. It can be said that the explanatory power of the model established with the FF5F risk-free interest rate and the model established with the inflation rate are very close.

There are 12 intersection portfolios of SL, SH, BL, BH, SR, SW, BR, BW, SC, SA, BC and BA used in factor calculations in the study. The explanatory power of these 12 portfolios as dependent variables separately, the FF5F model and the inflationary FF5F model are calculated for each country and presented in the tables.

Table 6: FF5F Regressions for 12 portfolios of Pakistan

\begin{tabular}{|c|c|c|c|c|c|c|c|c|}
\hline \multicolumn{9}{|c|}{ Pakistan } \\
\hline \multicolumn{9}{|c|}{$\mathrm{R}_{\mathrm{t}}-\mathrm{R}_{\mathrm{f}}(\mathrm{t})=\alpha+\mathrm{b}\left[\mathrm{R}_{\mathrm{M}}(\mathrm{t})-\mathrm{R}_{\mathrm{F}}(\mathrm{t})\right]+\mathrm{sSMB}(\mathrm{t})+\mathrm{hHML}(\mathrm{t})+\mathrm{rRMW}(\mathrm{t})+\mathrm{cCMA}(\mathrm{t})+\mathrm{e}(\mathrm{t})$} \\
\hline & & $\alpha$ & Rm-Rf & SMB & HML & RMW & CMA & $\mathbf{R}^{2}$ \\
\hline \multirow{2}{*}{ SL } & Coeff. & $-0,004$ & 1,199 & 0,816 & $-0,408$ & $-0,187$ & 0,103 & \multirow{2}{*}{0,8195} \\
\hline & t-Stat & $-0,922$ & $14,453^{*}$ & $4,547^{*}$ & $-3,818^{*}$ & $-1,901^{* *}$ & 0,912 & \\
\hline \multirow{2}{*}{ SH } & Coeff. & 0,003 & 0,947 & 0,811 & 0,440 & $-0,206$ & $-0,221$ & \multirow{2}{*}{0,6492} \\
\hline & t-Stat & 0,573 & $8,505^{*}$ & $3,370^{*}$ & $3,070^{*}$ & $-1,561$ & $-1,464$ & \\
\hline \multirow{2}{*}{ BL } & Coeff. & $-0,001$ & 1,036 & 0,465 & $-1,343$ & $-0,361$ & $-0,340$ & \multirow{2}{*}{0,7769} \\
\hline & t-Stat & $-0,156$ & 9,144* & $1,898^{* *}$ & $-9,205^{*}$ & $-2,684^{*}$ & $-2,212^{* *}$ & \\
\hline \multirow{2}{*}{ BH } & Coeff. & $-0,008$ & 1,288 & 0,469 & $-0,191$ & $-0,342$ & $-0,016$ & \multirow{2}{*}{0,7917} \\
\hline & t-Stat & $-1,662$ & $13,554^{*}$ & $2,283^{* *}$ & $-1,563$ & $-3,031^{*}$ & $-0,127$ & \\
\hline \multirow{2}{*}{ SR } & Coeff. & 0,002 & 1,234 & 0,798 & $-0,425$ & 0,447 & $-0,048$ & \multirow{2}{*}{0,7313} \\
\hline & t-Stat & 0,398 & $12,804^{*}$ & $3,827^{*}$ & $-3,424^{*}$ & $3,908^{*}$ & $-0,371$ & \\
\hline \multirow{2}{*}{ SW } & Coeff. & $-0,004$ & 1,099 & 1,045 & $-0,443$ & $-0,891$ & 0,419 & \multirow{2}{*}{0,8988} \\
\hline & t-Stat & $-1,219$ & $15,076^{*}$ & $6,626^{*}$ & $-4,719^{*}$ & $-10,301^{*}$ & $4,241^{*}$ & \\
\hline \multirow{2}{*}{ BR } & Coeff. & $-0,002$ & 1,039 & $-0,100$ & 0,038 & 0,115 & 0,204 & \multirow{2}{*}{0,7129} \\
\hline & t-Stat & $-0,462$ & $12,513^{*}$ & $-0,558$ & 0,360 & 1,164 & $1,813^{* * *}$ & \\
\hline
\end{tabular}


Nevin ÖZER, Mehmet Akif ÖNCÜ \& Ali ÖZER

\begin{tabular}{|c|c|c|c|c|c|c|c|c|}
\hline \multirow{2}{*}{ BW } & Coeff. & 0,004 & 1,174 & $-0,347$ & 0,057 & $-0,548$ & $-0,264$ & \multirow{2}{*}{0,7751} \\
\hline & t-Stat & 0,916 & $12,096^{*}$ & $-1,655$ & 0,453 & $-4,756^{*}$ & $-2,004^{* *}$ & \\
\hline \multirow{2}{*}{ SC } & Coeff. & $-0,001$ & 1,168 & 1,213 & $-0,331$ & $-0,482$ & 0,532 & \multirow{2}{*}{0,7904} \\
\hline & t-Stat & $-0,175$ & $11,111^{*}$ & $5,335^{*}$ & $-2,441^{* *}$ & $-3,865^{*}$ & $3,728^{*}$ & \\
\hline \multirow{2}{*}{ SA } & Coeff. & 0,001 & 1,010 & 2,076 & $-0,706$ & $-0,878$ & $-0,938$ & \multirow{2}{*}{0,8039} \\
\hline & t-Stat & 0,146 & $9,330^{*}$ & $8,867^{*}$ & $-5,064^{*}$ & $-6,839 *$ & $-6,391^{*}$ & \\
\hline \multirow{2}{*}{ BC } & Coeff. & 0,002 & 0,980 & 0,567 & $-0,404$ & $-0,729$ & 0,396 & \multirow{2}{*}{0,8417} \\
\hline & t-Stat & 0,572 & $11,977^{*}$ & $3,203^{*}$ & $-3,832^{*}$ & $-7,510^{*}$ & $3,568^{*}$ & \\
\hline \multirow{2}{*}{ BA } & Coeff. & 0,001 & 1,139 & $-0,295$ & $-0,029$ & $-0,333$ & $-0,134$ & \multirow{2}{*}{0,7958} \\
\hline & t-Stat & 0,152 & $13,839^{*}$ & $-1,659$ & $-0,270$ & $-3,413^{*}$ & $-1,201$ & \\
\hline \multicolumn{9}{|c|}{$R_{t}-R_{E N F}(t)=\alpha+b\left[R_{M}(t)-R_{E N F}(t)\right]+\operatorname{sSMB}(t)+h H M L(t)+r R M W(t)+c C M A(t)+e(t)$} \\
\hline & & $\alpha$ & Rm-RInf & SMB & HML & RMW & CMA & $\mathbf{R}^{2}$ \\
\hline \multirow{2}{*}{ SL } & Coeff. & $-0,002$ & 1,196 & 0,827 & $-0,413$ & $-0,194$ & 0,103 & \multirow{2}{*}{0,8178} \\
\hline & t-Stat & $-0,566$ & $14,355^{*}$ & $4,591^{*}$ & $-3,851^{*}$ & $-1,968^{* *}$ & 0,907 & \\
\hline \multirow{2}{*}{ SH } & Coeff. & 0,003 & 0,947 & 0,811 & 0,440 & $-0,206$ & $-0,221$ & \multirow{2}{*}{0,6481} \\
\hline & t-Stat & 0,563 & $8,503^{*}$ & $3,371^{*}$ & $3,073^{*}$ & $-1,563$ & $-1,464$ & \\
\hline \multirow{2}{*}{ BL } & Coeff. & $-0,001$ & 1,036 & 0,466 & $-1,344$ & $-0,361$ & $-0,340$ & \multirow{2}{*}{0,7762} \\
\hline & t-Stat & $-0,148$ & $9,138^{*}$ & $1,901^{* *}$ & $-9,211^{*}$ & $-2,692^{*}$ & $-2,211^{* *}$ & \\
\hline \multirow{2}{*}{ BH } & Coeff. & $-0,007$ & 1,286 & 0,473 & $-0,193$ & $-0,345$ & $-0,016$ & \multirow{2}{*}{0,7904} \\
\hline & t-Stat & $-1,588$ & $13,516^{*}$ & $2,299^{* *}$ & $-1,576$ & $-3,058^{*}$ & $-0,123$ & \\
\hline \multirow{2}{*}{ SR } & Coeff. & 0,002 & 1,230 & 0,801 & $-0,427$ & 0,444 & $-0,048$ & \multirow{2}{*}{0,7295} \\
\hline & t-Stat & 0,459 & $12,757^{*}$ & $3,842^{*}$ & $-3,436^{*}$ & $3,886^{*}$ & $-0,365$ & \\
\hline \multirow{2}{*}{ SW } & Coeff. & $-0,004$ & 1,096 & 1,047 & $-0,444$ & $-0,893$ & 0,420 & \multirow{2}{*}{0,8981} \\
\hline & t-Stat & $-1,185$ & $15,017^{*}$ & $6,640^{*}$ & $-4,731^{*}$ & $-10,342^{*}$ & $4,247^{*}$ & \\
\hline \multirow{2}{*}{ BR } & Coeff. & $-0,002$ & 1,036 & $-0,099$ & 0,038 & 0,113 & 0,205 & \multirow{2}{*}{0,7113} \\
\hline & t-Stat & $-0,449$ & $12,478^{*}$ & $-0,551$ & 0,353 & 1,149 & $1,819^{* * *}$ & \\
\hline \multirow{2}{*}{ BW } & Coeff. & 0,004 & 1,171 & $-0,345$ & 0,055 & $-0,550$ & $-0,263$ & \multirow{2}{*}{0,7739} \\
\hline & t-Stat & 0,962 & $12,064^{*}$ & $-1,644$ & 0,443 & $-4,782^{*}$ & $-1,998^{* *}$ & \\
\hline \multirow{2}{*}{ SC } & Coeff. & $-0,001$ & 1,167 & 1,216 & $-0,332$ & $-0,484$ & 0,532 & \multirow{2}{*}{0,7894} \\
\hline & t-Stat & $-0,135$ & $11,089^{*}$ & $5,346^{*}$ & $-2,449^{* *}$ & $-3,886^{*}$ & $3,729^{*}$ & \\
\hline & Coeff. & 0,001 & 1,003 & 2,078 & $-0,707$ & $-0,882$ & $-0,936$ & \\
\hline $\mathrm{SA}$ & t-Stat & 0,152 & $9,270^{*}$ & 8,883* & $-5,077^{*}$ & $-6,880^{*}$ & $-6,378^{*}$ & $0,00<0$ \\
\hline
\end{tabular}


Fama French 5 Factor Model Versus Alternative Fama French 5 Factor Model

\begin{tabular}{|l|l|l|l|l|l|l|l|l|}
\hline \multirow{2}{*}{ BC } & Coeff. & 0,002 & 0,974 & 0,569 & $-0,405$ & $-0,733$ & 0,398 & \multirow{2}{*}{0,8406} \\
\cline { 2 - 8 } & t-Stat & 0,572 & $11,898^{*}$ & $3,219^{*}$ & $-3,848^{*}$ & $-7,565^{*}$ & $3,586^{*}$ & \\
\hline \multirow{2}{*}{ BA } & Coeff. & 0,001 & 1,137 & $-0,293$ & $-0,030$ & $-0,335$ & $-0,134$ & \multirow{2}{*}{0,7946} \\
\cline { 2 - 8 } & t-Stat & 0,195 & $13,803^{*}$ & $-1,648$ & $-0,279$ & $-3,437^{*}$ & $-1,196$ & \\
\hline
\end{tabular}

Note: ${ }^{*},{ }^{* *},{ }^{* * *}$ denote statistical significance at the $1 \%, 5 \%$ and $10 \%$ levels, respectively.

Looking at the FF5F regression results of 12 portfolios calculated for Pakistan in Table 6 , it is seen that $\alpha$ values are insignificant in both the original model and the inflation model. This shows that the 5 factor model is effective in explaining portfolio returns. Both the risk-free interest rate and the over-market return based on inflation are significant in all models. For both original and inflated FF5F, SMB factor is significant and explanatory factors in 9 models, HML factor in 8 models, RMW factor in 10 models and CMA factor in $5 \%$ of 6 models. Significant factors and $\mathrm{R}^{2}$ in both models are similar. The explanatory power of $\mathrm{R}^{2} \mathrm{~s}$ in all models is quite high. This shows that both the original version and the inflationary version of the FF5F model are effective in explaining the returns from portfolios. In addition, the fact of being insignificant of $\alpha$ values for both models shows that they are effective in explaining excess returns.

Table 7: FF5F Regressions for 12 portfolios of Indonesia

\begin{tabular}{|c|c|c|c|c|c|c|c|c|}
\hline \multicolumn{9}{|c|}{ Indonesia } \\
\hline \multicolumn{9}{|c|}{$R_{t}-R_{f}(t)=\alpha+b\left[R_{M}(t)-R_{F}(t)\right]+s S M B(t)+h H M L(t)+r R M W(t)+c C M A(t)+e(t)$} \\
\hline & & $\alpha$ & Rm-Rf & SMB & HML & RMW & CMA & $\mathbf{R}^{2}$ \\
\hline \multirow{2}{*}{ SL } & Coeff. & 0,011 & 0,701 & 0,967 & $-0,433$ & 0,701 & $-0,578$ & \multirow{2}{*}{0,5262} \\
\hline & t-Stat & $1,872^{* * *}$ & $4,953^{*}$ & $4,192^{*}$ & $-3,538^{*}$ & $4,761^{*}$ & $-2,304^{* *}$ & \\
\hline \multirow{2}{*}{ SH } & Coeff. & 0,005 & 0,890 & 0,455 & 1,070 & $-0,024$ & $-0,304$ & \multirow{2}{*}{0,7814} \\
\hline & $\mathrm{t}$-Stat & 0,744 & $5,780^{*}$ & $1,813^{* * *}$ & $8,040^{*}$ & $-0,152$ & $-1,115$ & \\
\hline \multirow{2}{*}{ BL } & Coeff. & 0,002 & 0,934 & $-0,001$ & $-0,763$ & $-0,309$ & $-0,208$ & \multirow{2}{*}{0,6215} \\
\hline & t-Stat & 0,443 & $7,013^{*}$ & $-0,003$ & $-6,622^{*}$ & $-2,234^{* *}$ & $-0,883$ & \\
\hline \multirow{2}{*}{ BH } & Coeff. & 0,009 & 0,745 & 0,512 & $-0,266$ & 0,416 & $-0,482$ & \multirow{2}{*}{0,3416} \\
\hline & $\mathrm{t}$-Stat & 1,358 & $4,833^{*}$ & $2,036^{* *}$ & $-1,995^{* *}$ & $2,593^{* *}$ & $-1,765^{* * *}$ & \\
\hline \multirow{2}{*}{ SR } & Coeff. & 0,006 & 0,849 & 0,893 & $-0,470$ & 0,828 & $-0,482$ & \multirow{2}{*}{0,6036} \\
\hline & $\mathrm{t}$-Stat & 1,080 & $6,229 *$ & $4,022^{*}$ & $-3,993^{*}$ & $5,841^{*}$ & $-1,996^{* *}$ & \\
\hline \multirow{2}{*}{ SW } & Coeff. & 0,011 & 1,168 & 1,103 & 0,540 & $-0,516$ & 0,602 & \multirow{2}{*}{0,7381} \\
\hline & $\mathrm{t}$-Stat & 1,474 & $6,577^{*}$ & $3,811^{*}$ & $3,515^{*}$ & $-2,792^{*}$ & $1,914^{* * *}$ & \\
\hline
\end{tabular}


Nevin ÖZER, Mehmet Akif ÖNCÜ \& Ali ÖZER

\begin{tabular}{|c|c|c|c|c|c|c|c|c|}
\hline \multirow{2}{*}{ BR } & Coeff. & 0,007 & 1,088 & $-0,216$ & 0,999 & 0,543 & 0,345 & \multirow{2}{*}{0,6919} \\
\hline & t-Stat & 1,102 & $6,957^{*}$ & $-0,849$ & $7,389^{*}$ & $3,341^{*}$ & 1,244 & \\
\hline \multirow{2}{*}{ BW } & Coeff. & 0,002 & 0,769 & $-0,426$ & $-0,011$ & $-0,114$ & $-0,740$ & \multirow{2}{*}{0,4861} \\
\hline & t-Stat & 0,511 & $6,811^{*}$ & $-2,316^{* *}$ & $-0,113$ & $-0,968$ & $-3,698^{*}$ & \\
\hline \multirow{2}{*}{ SC } & Coeff. & $-0,001$ & 0,787 & 0,460 & $-0,341$ & $-0,223$ & 0,370 & \multirow{2}{*}{0,4830} \\
\hline & t-Stat & $-0,191$ & $7,018^{*}$ & $2,518^{* *}$ & $-3,520^{*}$ & $-1,912^{* *}$ & $1,861^{* * *}$ & \\
\hline \multirow{2}{*}{ SA } & Coeff. & $-0,006$ & 0,871 & 0,727 & $-0,664$ & $-0,576$ & $-0,297$ & \multirow{2}{*}{0,5089} \\
\hline & t-Stat & $-1,094$ & $6,785^{*}$ & $3,476^{*}$ & $-5,983^{*}$ & $-4,321^{*}$ & $-1,308$ & \\
\hline \multirow{2}{*}{ BC } & Coeff. & 0,001 & 0,907 & $-0,499$ & $-0,290$ & $-0,350$ & 0,865 & \multirow{2}{*}{0,4774} \\
\hline & t-Stat & 0,032 & $6,361^{*}$ & $-2,146^{* *}$ & $-2,354^{* *}$ & $-2,363^{* *}$ & $3,423^{*}$ & \\
\hline \multirow{2}{*}{ BA } & Coeff. & 0,005 & 0,823 & $-0,765$ & 0,032 & 0,003 & $-0,468$ & \multirow{2}{*}{0,5030} \\
\hline & t-Stat & 1,038 & $6,919 *$ & $-3,945^{*}$ & 0,313 & 0,027 & $-2,221^{* *}$ & \\
\hline
\end{tabular}

$R_{t}-R_{E N F}(t)=\alpha+b\left[R_{M}(t)-R_{E N F}(t)\right]+\operatorname{sSMB}(t)+h H M L(t)+\operatorname{rRMW}(t)+c C M A(t)+e(t)$

\begin{tabular}{|c|c|c|c|c|c|c|c|c|}
\hline & & $\alpha$ & $\begin{array}{l}\text { Rm- } \\
\text { RInf }\end{array}$ & SMB & HML & RMW & CMA & $\mathbf{R}^{2}$ \\
\hline \multirow{2}{*}{ SL } & Coeff. & 0,011 & 0,697 & 0,969 & $-0,434$ & 0,700 & $-0,578$ & \multirow{2}{*}{0,5256} \\
\hline & t-Stat & $1,977^{* * *}$ & $4,932 *$ & $4,202^{*}$ & $-3,544^{*}$ & $4,759 *$ & $-2,306^{* *}$ & \\
\hline \multirow{2}{*}{ SH } & Coeff. & 0,005 & 0,892 & 0,454 & 1,070 & $-0,025$ & $-0,304$ & \multirow{2}{*}{0,7814} \\
\hline & t-Stat & 0,780 & $5,797^{*}$ & $1,810^{* * *}$ & $8,039^{*}$ & $-0,153$ & $-1,114$ & \\
\hline \multirow{2}{*}{ BL } & Coeff. & 0,003 & 0,937 & $-0,002$ & $-0,763$ & $-0,310$ & $-0,208$ & \multirow{2}{*}{0,6223} \\
\hline & t-Stat & 0,468 & $7,039 *$ & $-0,007$ & $-6,620^{*}$ & $-2,234^{* *}$ & $-0,882$ & \\
\hline \multirow{2}{*}{ BH } & Coeff. & 0,009 & 0,742 & 0,513 & $-0,267$ & 0,415 & $-0,482$ & \multirow{2}{*}{0,3406} \\
\hline & t-Stat & 1,439 & $4,817^{*}$ & $2,041^{* *}$ & $-1,999 * *$ & $2,590^{*}$ & $-1,765^{* * *}$ & \\
\hline \multirow{2}{*}{ SR } & Coeff. & 0,006 & 0,850 & 0,893 & $-0,471$ & 0,827 & $-0,482$ & \multirow{2}{*}{0,6034} \\
\hline & t-Stat & 1,135 & $6,238^{*}$ & $4,021^{*}$ & $-3,994^{*}$ & $5,839^{*}$ & $-1,995^{* * *}$ & \\
\hline \multirow{2}{*}{ SW } & Coeff. & 0,010 & 1,174 & 1,101 & 0,540 & $-0,515$ & 0,602 & \multirow{2}{*}{0,7386} \\
\hline & t-Stat & 1,436 & $6,615^{*}$ & $3,806^{*}$ & $3,519^{*}$ & $-2,790^{*}$ & $1,915^{* * *}$ & \\
\hline \multirow{2}{*}{ BR } & Coeff. & 0,007 & 1,091 & $-0,218$ & 0,999 & 0,544 & 0,345 & \multirow{2}{*}{0,6922} \\
\hline & t-Stat & 1,080 & $6,985^{*}$ & $-0,854$ & $7,392^{*}$ & $3,343^{*}$ & 1,244 & \\
\hline \multirow{2}{*}{ BW } & Coeff. & 0,003 & 0,768 & $-0,426$ & $-0,011$ & $-0,114$ & $-0,739$ & \multirow{2}{*}{0,4860} \\
\hline & $\mathrm{t}$-Stat & 0,609 & $6,806^{*}$ & $-2,314^{* *}$ & $-0,116$ & $-0,973$ & $-3,698^{*}$ & \\
\hline SC & Coeff. & 0,001 & 0,786 & 0,461 & $-0,342$ & $-0,223$ & 0,370 & 0,4832 \\
\hline
\end{tabular}


Fama French 5 Factor Model Versus Alternative Fama French 5 Factor Model

\begin{tabular}{|l|l|l|l|l|l|l|l|l|}
\hline & t-Stat & $-0,103$ & $7,016^{*}$ & $2,521^{* *}$ & $-3,523^{*}$ & $-1,916^{* * *}$ & $1,862^{* * *}$ & \\
\hline \multirow{2}{*}{ SA } & Coeff. & $-0,005$ & 0,871 & 0,727 & $-0,664$ & $-0,577$ & $-0,297$ & \multirow{2}{*}{0,5096} \\
\cline { 2 - 8 } & t-Stat & $-1,050$ & $6,791^{*}$ & $3,476^{*}$ & $-5,983^{*}$ & $-4,323^{*}$ & $-1,307$ & \\
\hline \multirow{2}{*}{ BC } & Coeff. & 0,0001 & 0,908 & $-0,499$ & $-0,290$ & $-0,350$ & 0,865 & \multirow{2}{*}{0,4783} \\
\cline { 2 - 8 } & t-Stat & 0,063 & $6,374^{*}$ & $-2,148^{* *}$ & $-2,354^{* *}$ & $-2,364^{* *}$ & $3,424^{*}$ & \\
\hline \multirow{2}{*}{ BA } & Coeff. & 0,005 & 0,823 & $-0,765$ & 0,032 & 0,003 & $-0,468$ & \multirow{2}{*}{0,5033} \\
\cline { 2 - 8 } & t-Stat & 1,111 & $6,924^{*}$ & $-3,945^{*}$ & 0,312 & 0,024 & $-2,220^{* *}$ & \\
\hline
\end{tabular}

Note: ${ }^{*}, * *, * *$ denote statistical significance at the $1 \%, 5 \%$ and $10 \%$ levels, respectively.

When looked FF5F regression results of 12 portfolios calculated for Indonesia in Table 7, $\alpha$ value in both original model and inflated model at 5 $\%$ level are insignificant. This shows that the 5 factor model is effective in explaining portfolio returns. Both the risk-free interest rate and the overmarket return based on inflation have proved meaningful in all models as in Pakistan. For both the original and inflated FF5F, the SMB factor is significant in 9 models and the HML factor is significant at $5 \%$ in 10 models. In the riskfree interest rate based FF5F model, the RMW factor was significant in 9 models, and in the FF5F model based on inflation, at $5 \%$ in 8 models. The CMA factor is significant in 5 models in the original FF5F model, and in 5\% in 4 models in the inflation model. The original model has little advantage over the inflation model in terms of significant factors. Although the explanatory power of $\mathrm{R}^{2} \mathrm{~s}$ in all models is not as strong as Pakistan, it is generally above $50 \%$. It shows that both the original version and the inflationary version of the FF5F model are effective in explaining the returns from portfolios. In addition, at $5 \%$ of $\alpha$ value for both models, being all of them insignificant shows that they are effective in explaining excess returns.

Table 8: FF5F Regressions for 12 portfolios of Malaysia

\begin{tabular}{|c|c|c|c|c|c|c|c|c|}
\hline \multicolumn{9}{|c|}{ Malaysia } \\
\hline \multicolumn{9}{|c|}{$R_{t}-R_{f}(t)=\alpha+b\left[R_{M}(t)-R_{F}(t)\right]+s S M B(t)+h H M L(t)+r R M W(t)+c C M A(t)+e(t)$} \\
\hline & & $\alpha$ & Rm-Rf & SMB & HML & RMW & CMA & $\mathbf{R}^{2}$ \\
\hline \multirow{2}{*}{ SL } & Coeff. & 0,0002 & 0,337 & 0,294 & $-0,056$ & 0,530 & $-0,051$ & \multirow{2}{*}{0,2485} \\
\hline & t-Stat & $-0,091$ & $2,787^{*}$ & 1,178 & $-0,345$ & $3,426^{*}$ & $-0,343$ & \\
\hline \multirow{2}{*}{ SH } & Coeff. & 0,005 & 0,325 & $-0,082$ & 0,767 & $-0,118$ & 0,033 & \multirow{2}{*}{0,310} \\
\hline & $\mathrm{t}$-Stat & 1,569 & $2,618^{* *}$ & $-0,318$ & $4,572^{*}$ & $-0,744$ & 0,212 & \\
\hline \multirow{2}{*}{ BL } & Coeff. & 0,005 & 0,358 & $-0,396$ & $-1,035$ & $-0,137$ & 0,026 & \multirow{2}{*}{0,532} \\
\hline & t-Stat & 1,640 & $2,881^{*}$ & $-1,540$ & $-6,163^{*}$ & $-0,862$ & 0,172 & \\
\hline
\end{tabular}


Nevin ÖZER, Mehmet Akif ÖNCÜ \& Ali ÖZER

\begin{tabular}{|c|c|c|c|c|c|c|c|c|}
\hline \multirow{2}{*}{ BH } & Coeff. & 0,0004 & 0,370 & $-0,020$ & 0,143 & 0,511 & $-0,057$ & \multirow{2}{*}{0,213} \\
\hline & t-Stat & $-0,016$ & $2,981^{*}$ & $-0,079$ & 0,853 & $3,216^{*}$ & $-0,374$ & \\
\hline \multirow{2}{*}{ SR } & Coeff. & 0,0006 & 0,397 & 0,165 & 0,041 & 0,950 & $-0,035$ & \multirow{2}{*}{0,410} \\
\hline & t-Stat & 0,022 & $3,194^{*}$ & 0,640 & 0,243 & $5,960^{*}$ & $-0,228$ & \\
\hline \multirow{2}{*}{ SW } & Coeff. & 0,002 & 0,387 & 0,724 & $-0,063$ & $-0,418$ & 0,034 & \multirow{2}{*}{0,322} \\
\hline & t-Stat & 0,910 & $3,862^{*}$ & $3,498^{*}$ & $-0,463$ & $-3,253^{*}$ & 0,275 & \\
\hline \multirow{2}{*}{ BR } & Coeff. & 0,004 & 0,279 & $-0,452$ & 0,588 & 0,371 & $-0,171$ & \multirow{2}{*}{0,225} \\
\hline & t-Stat & 1,224 & $2,340^{* *}$ & $-1,831^{* * *}$ & $3,653^{*}$ & $2,429^{* *}$ & $-1,157$ & \\
\hline \multirow{2}{*}{ BW } & Coeff. & 0,001 & 0,290 & $-1,011$ & 0,692 & $-0,261$ & $-0,240$ & \multirow{2}{*}{0,269} \\
\hline & t-Stat & 0,451 & $2,270^{* *}$ & $-3,833^{*}$ & $4,015^{*}$ & $-1,593$ & $-1,519$ & \\
\hline \multirow{2}{*}{ SC } & Coeff. & 0,002 & 0,398 & 0,259 & 0,254 & $-0,181$ & 0,264 & \multirow{2}{*}{0,255} \\
\hline & $\mathrm{t}$-Stat & 0,776 & $3,268^{*}$ & 1,029 & 1,547 & $-1,160$ & $1,756^{* * *}$ & \\
\hline \multirow{2}{*}{ SA } & Coeff. & 0,010 & 0,281 & 0,384 & 0,114 & $-0,162$ & $-0,190$ & \multirow{2}{*}{0,154} \\
\hline & t-Stat & $3,830^{*}$ & $2,536^{* *}$ & $1,677^{* *}$ & 0,765 & $-1,144$ & $-1,385$ & \\
\hline \multirow{2}{*}{ BC } & Coeff. & 0,009 & 0,355 & $-1,126$ & 0,265 & 0,068 & 1,021 & \multirow{2}{*}{0,591} \\
\hline & t-Stat & $3,429^{*}$ & $3,383^{*}$ & $-5,185^{*}$ & $1,867^{* *}$ & 0,504 & $7,855^{*}$ & \\
\hline \multirow{2}{*}{ BA } & Coeff. & 0,001 & 0,472 & $-1,251$ & 0,404 & 0,049 & $-0,525$ & \multirow{2}{*}{0,373} \\
\hline & t-Stat & 0,269 & $4,159^{*}$ & $-5,331^{*}$ & $2,640^{*}$ & 0,338 & $-3,735^{*}$ & \\
\hline \multicolumn{9}{|c|}{$\mathrm{R}_{\mathrm{t}}-\mathrm{R}_{\mathrm{ENF}}(\mathrm{t})=\alpha+\mathrm{b}\left[\mathrm{R}_{\mathrm{M}}(\mathrm{t})-\mathrm{R}_{\mathrm{ENF}}(\mathrm{t})\right]+\operatorname{sSMB}(\mathrm{t})+\mathrm{hHML}(\mathrm{t})+\mathrm{rRMW}(\mathrm{t})+\mathrm{cCMA}(\mathrm{t})+\mathrm{e}(\mathrm{t})$} \\
\hline & & $\alpha$ & $\begin{array}{l}\text { Rm- } \\
\text { RInf }\end{array}$ & SMB & HML & RMW & CMA & $\mathbf{R}^{2}$ \\
\hline \multirow{2}{*}{ SL } & Coeff. & 0,0002 & 0,335 & 0,293 & $-0,054$ & 0,530 & $-0,056$ & \multirow{2}{*}{0,247} \\
\hline & t-Stat & 0,081 & $2,769^{*}$ & 1,175 & $-0,333$ & $3,427^{*}$ & $-0,376$ & \\
\hline \multirow{2}{*}{ SH } & Coeff. & 0,005 & 0,318 & $-0,081$ & 0,768 & $-0,119$ & 0,030 & \multirow{2}{*}{0,310} \\
\hline & t-Stat & $1,746^{* * *}$ & $2,567^{* *}$ & $-0,318$ & $4,596^{*}$ & $-0,751$ & 0,194 & \\
\hline \multirow{2}{*}{ BL } & Coeff. & 0,005 & 0,352 & $-0,396$ & $-1,033$ & $-0,138$ & 0,024 & \multirow{2}{*}{0,532} \\
\hline & t-Stat & $1,808^{* * *}$ & $2,830^{*}$ & $-1,543$ & $-6,171^{*}$ & $-0,870$ & 0,156 & \\
\hline \multirow{2}{*}{ BH } & Coeff. & 0,0004 & 0,368 & $-0,021$ & 0,145 & 0,511 & $-0,062$ & \multirow{2}{*}{0,213} \\
\hline & t-Stat & 0,143 & $2,963^{*}$ & $-0,082$ & 0,864 & $3,218^{*}$ & $-0,404$ & \\
\hline \multirow{2}{*}{ SR } & Coeff. & 0,001 & 0,394 & 0,164 & 0,043 & 0,950 & $-0,039$ & \multirow{2}{*}{0,409} \\
\hline & t-Stat & 0,174 & $3,168^{*}$ & 0,639 & 0,254 & $5,964^{*}$ & $-0,253$ & \\
\hline SW & Coeff. & 0,003 & 0,383 & 0,724 & $-0,061$ & $-0,418$ & 0,031 & 0,320 \\
\hline
\end{tabular}


Fama French 5 Factor Model Versus Alternative Fama French 5 Factor Model

\begin{tabular}{|c|c|c|c|c|c|c|c|c|}
\hline & t-Stat & 1,105 & $3,826^{*}$ & $3,505^{*}$ & $-0,452$ & $-3,262^{*}$ & 0,247 & \\
\hline \multirow{2}{*}{ BR } & Coeff. & 0,004 & 0,275 & $-0,452$ & 0,590 & 0,371 & $-0,175$ & \multirow{2}{*}{0,226} \\
\hline & t-Stat & 1,418 & $2,303^{* *}$ & $-1,836^{* * *}$ & $3,673^{*}$ & $2,432^{* *}$ & $-1,189$ & \\
\hline \multirow{2}{*}{ BW } & Coeff. & 0,002 & 0,286 & $-1,012$ & 0,694 & $-0,261$ & $-0,244$ & \multirow{2}{*}{0,270} \\
\hline & t-Stat & 0,627 & $2,240^{* *}$ & $-3,841^{*}$ & $4,032^{*}$ & $-1,597$ & $-1,552$ & \\
\hline \multirow{2}{*}{ SC } & Coeff. & 0,003 & 0,391 & 0,259 & 0,256 & $-0,182$ & 0,262 & \multirow{2}{*}{0,252} \\
\hline & t-Stat & 0,933 & $3,218^{*}$ & 1,034 & 1,561 & $-1,168$ & $1,748^{* * *}$ & \\
\hline \multirow{2}{*}{ SA } & Coeff. & 0,011 & 0,273 & 0,384 & 0,116 & $-0,163$ & $-0,193$ & \multirow{2}{*}{0,153} \\
\hline & t-Stat & $4,056^{*}$ & $2,477^{* *}$ & $1,686^{* * *}$ & 0,781 & $-1,154$ & $-1,417$ & \\
\hline \multirow{2}{*}{ BC } & Coeff. & 0,009 & 0,349 & $-1,126$ & 0,266 & 0,067 & 1,018 & \multirow{2}{*}{0,590} \\
\hline & t-Stat & $3,639^{*}$ & $3,329 *$ & $-5,203^{*}$ & $1,887^{* * *}$ & 0,500 & $7,878^{*}$ & \\
\hline \multirow{2}{*}{ BA } & Coeff. & 0,001 & 0,466 & $-1,250$ & 0,406 & 0,049 & $-0,527$ & \multirow{2}{*}{0,374} \\
\hline & t-Stat & 0,415 & $4,113^{*}$ & $-5,342^{*}$ & $2,656^{*}$ & 0,335 & $-3,766^{*}$ & \\
\hline
\end{tabular}

Note: ${ }^{*}, * *, * *$ denote statistical significance at the $1 \%, 5 \%$ and $10 \%$ levels, respectively.

Looking at the FF5F regression results of 12 portfolios calculated for Malaysia in Table 8, it is seen that the $\alpha$ values are significant at $1 \%$ in the models that explain the excess returns of SA and SC portfolios in both the original model and the inflation model. Although there is no other significant $\alpha$ value in $5 \%$, the inflation model also has 2 more significant $\alpha$ values in $10 \%$. It can be said that the 5-factor model is generally effective in explaining portfolio excess returns, but the efficiency obtained for Malaysia is lower than that for Indonesia and Pakistan. Both the risk-free interest rate and the over-market return based on inflation were significant in all models, as in Pakistan and Indonesia. For both the original and inflated FF5F, the RMW factor is significant in 5 models, while the CMA factor is significant at $5 \%$ in 2 models. In the risk-free interest rate based FF5F model, the SMB factor was found to be significant in 5 models, and in the FF5F model based on inflation, at $5 \%$ in 4 models. The HML factor is significant in 6 models in the original FF5F model and 5\% in 5 models with inflation. The original model has little advantage over the inflation model in terms of significant factors. The explanatory power of $\mathrm{R}^{2}$ in all models has decreased considerably in Malaysia compared to Pakistan and Indonesia and is mostly below $50 \%$. It is seen that both the original version and the inflationary version of the FF5F model are effective in explaining 10 portfolios from 12 portfolios in explaining the returns from portfolios. 
Nevin ÖZER, Mehmet Akif ÖNCÜ \& Ali ÖZER

Table 9: FF5F Regressions for 12 portfolios of Turkey

\begin{tabular}{|c|c|c|c|c|c|c|c|c|}
\hline \multicolumn{9}{|c|}{ Turkey } \\
\hline \multicolumn{9}{|c|}{$\mathrm{R}_{\mathrm{t}}-\mathrm{R}_{\mathrm{f}}(\mathrm{t})=\alpha+\mathrm{b}\left[\mathrm{R}_{\mathrm{M}}(\mathrm{t})-\mathrm{R}_{\mathrm{F}}(\mathrm{t})\right]+\mathrm{sSMB}(\mathrm{t})+\mathrm{hHML}(\mathrm{t})+\mathrm{rRMW}(\mathrm{t})+\mathrm{cCMA}(\mathrm{t})+\mathrm{e}(\mathrm{t})$} \\
\hline & & $\alpha$ & Rm-Rf & SMB & HML & RMW & CMA & $\mathbf{R}^{2}$ \\
\hline \multirow{2}{*}{ SL } & Coeff. & 0,043 & 1,396 & 1,451 & $-0,891$ & $-0,088$ & 0,554 & \multirow{2}{*}{0,4853} \\
\hline & t-Stat & 0,124 & $3,724 *$ & $4,196^{*}$ & $-3,695^{*}$ & $-3,458^{*}$ & $2,447^{* *}$ & \\
\hline \multirow{2}{*}{ SH } & Coeff. & 0,007 & 0,769 & 1,140 & 1,266 & 0,033 & $-0,073$ & \multirow{2}{*}{0,4639} \\
\hline & t-Stat & 0,842 & $4,592^{*}$ & $3,387^{*}$ & $3,907^{*}$ & 0,178 & $-0,208$ & \\
\hline \multirow{2}{*}{ BL } & Coeff. & 0,001 & 0,950 & 0,118 & $-0,732$ & $-0,313$ & $-0,208$ & \multirow{2}{*}{0,6060} \\
\hline & t-Stat & 0,259 & $6,607^{*}$ & 0,340 & $-6,926^{*}$ & $-2,374^{* *}$ & $-0,619$ & \\
\hline \multirow{2}{*}{ BH } & Coeff. & 0,044 & 0,844 & 0,546 & $-0,185$ & 1,165 & $-0,421$ & \multirow{2}{*}{0,3868} \\
\hline & t-Stat & 0,148 & $4,079^{*}$ & $2,374^{* *}$ & $-1,656^{* *}$ & $3,331^{*}$ & $-1,924^{* *}$ & \\
\hline \multirow{2}{*}{ SR } & Coeff. & 0,043 & 0,399 & 0,865 & $-0,641$ & 0,848 & $-0,219$ & \multirow{2}{*}{0,6328} \\
\hline & t-Stat & 1,025 & $3,525^{*}$ & $4,159 *$ & $-4,484^{*}$ & $5,234^{*}$ & $-1,927^{* *}$ & \\
\hline \multirow{2}{*}{ SW } & Coeff. & 0,050 & 1,391 & 1,212 & 0,557 & $-0,561$ & 0,946 & \multirow{2}{*}{0,6981} \\
\hline & t-Stat & 1,036 & $6,549 *$ & $4,696^{*}$ & $3,258^{*}$ & $-2,689 *$ & $2,955^{* *}$ & \\
\hline \multirow{2}{*}{ BR } & Coeff. & 0,048 & 1,392 & 0,395 & 0,939 & 0,110 & 0,660 & \multirow{2}{*}{0,5544} \\
\hline & t-Stat & 0,613 & $3,816^{*}$ & $3,083^{*}$ & $4,148^{*}$ & 0,588 & $3,169 *$ & \\
\hline \multirow{2}{*}{ BW } & Coeff. & 0,028 & 0,125 & 0,574 & 0,652 & 0,073 & $-0,913$ & \multirow{2}{*}{0,4215} \\
\hline & t-Stat & 0,947 & 0,751 & $3,465^{*}$ & $3,884^{*}$ & 0,362 & $-4,298^{*}$ & \\
\hline \multirow{2}{*}{ SC } & Coeff. & $-0,061$ & 0,348 & 0,464 & 0,386 & $-0,253$ & 0,286 & \multirow{2}{*}{0,4397} \\
\hline & t-Stat & $-0,273$ & 0,487 & $2,464^{* *}$ & $3,334^{*}$ & $-2,295^{* *}$ & $3,832^{*}$ & \\
\hline \multirow{2}{*}{ SA } & Coeff. & $-0,035$ & 0,494 & 0,757 & 0,254 & $-0,039$ & 0,305 & \multirow{2}{*}{0,3228} \\
\hline & t-Stat & $-2,719^{*}$ & $4,920^{*}$ & $3,721^{*}$ & 0,980 & $-0,215$ & $4,305^{*}$ & \\
\hline \multirow{2}{*}{ BC } & Coeff. & $-0,051$ & 0,321 & $-1,143$ & 0,543 & 0,458 & $-0,192$ & \multirow{2}{*}{0,4546} \\
\hline & t-Stat & $-6,011^{*}$ & 0,136 & $-5,018^{*}$ & $2,422^{* *}$ & $2,107^{* *}$ & $-1,415$ & \\
\hline \multirow{2}{*}{ BA } & Coeff. & 0,038 & 0,361 & 0,870 & $-0,051$ & 0,327 & $-0,221$ & \multirow{2}{*}{0,4577} \\
\hline & t-Stat & 0,671 & $8,167^{*}$ & $4,089 *$ & $-0,446$ & $3,087^{*}$ & $-1,453$ & \\
\hline \multicolumn{9}{|c|}{$R_{t}-R_{E N F}(t)=\alpha+b\left[R_{M}(t)-R_{E N F}(t)\right]+\operatorname{sSMB}(t)+h H M L(t)+r R M W(t)+c C M A(t)+e(t)$} \\
\hline & & $\alpha$ & $\begin{array}{l}\text { Rm- } \\
\text { RInf }\end{array}$ & SMB & HML & RMW & CMA & $\mathbf{R}^{2}$ \\
\hline SL & Coeff. & 0,041 & 1,399 & 1,476 & $-0,751$ & $-0,118$ & 0,525 & 0,4755 \\
\hline
\end{tabular}


Fama French 5 Factor Model Versus Alternative Fama French 5 Factor Model

\begin{tabular}{|c|c|c|c|c|c|c|c|c|}
\hline & t-Stat & 0,049 & $3,803^{*}$ & $4,264^{*}$ & $-3,550^{*}$ & $-3,613^{*}$ & $2,344^{* *}$ & \\
\hline \multirow{2}{*}{ SH } & Coeff. & 0,033 & 0,492 & 0,264 & 1,305 & 0,007 & $-0,001$ & \multirow{2}{*}{0,4602} \\
\hline & t-Stat & 0,583 & $4,829^{*}$ & $3,448^{*}$ & $3,148^{*}$ & 0,037 & $-0,004$ & \\
\hline \multirow{2}{*}{ BL } & Coeff. & $-0,040$ & 0,944 & 0,139 & 0,744 & $-0,340$ & $-0,148$ & \multirow{2}{*}{0,6037} \\
\hline & t-Stat & 0,282 & $6,631^{*}$ & 0,405 & $5,115^{*}$ & $-2,227^{* *}$ & $-0,444$ & \\
\hline \multirow{2}{*}{ BH } & Coeff. & 0,042 & 0,847 & 0,669 & $-0,147$ & 1,093 & $-0,456$ & \multirow{2}{*}{0,3818} \\
\hline & t-Stat & 0,187 & $4,159^{*}$ & $2,137^{* *}$ & $-1,525^{* *}$ & $3,470^{*}$ & $-1,950^{* *}$ & \\
\hline \multirow{2}{*}{$\mathbf{S R}$} & Coeff. & 0,039 & 0,419 & 0,891 & $-0,698$ & 0,878 & 0,298 & \multirow{2}{*}{0,6460} \\
\hline & t-Stat & 0,706 & $3,723^{*}$ & $4,216^{*}$ & $-4,333^{*}$ & $5,376^{*}$ & $1,963^{* *}$ & \\
\hline \multirow{2}{*}{ SW } & Coeff. & 0,046 & 1,417 & 1,239 & 0,512 & $-0,591$ & 0,936 & \multirow{2}{*}{0,7149} \\
\hline & t-Stat & 1,172 & $6,823^{*}$ & $4,772^{*}$ & $3,054^{*}$ & $-2,572$ & $2,121^{* *}$ & \\
\hline \multirow{2}{*}{ BR } & Coeff. & 0,044 & 1,413 & 0,421 & 0,783 & $-0,140$ & 0,740 & \multirow{2}{*}{0,5220} \\
\hline & t-Stat & 0,369 & $4,031^{*}$ & $3,146^{*}$ & $3,312^{*}$ & $-0,743$ & $3,393^{*}$ & \\
\hline \multirow{2}{*}{ BW } & Coeff. & 0,024 & 0,148 & 0,595 & 0,588 & 0,049 & $-0,779$ & \multirow{2}{*}{0,4395} \\
\hline & $\mathrm{t}$-Stat & 0,713 & 0,980 & $3,509^{*}$ & $3,004^{*}$ & 0,243 & $-3,469^{*}$ & \\
\hline \multirow{2}{*}{ SC } & Coeff. & $-0,056$ & 0,382 & 0,494 & 0,336 & 0,221 & $-0,295$ & \multirow{2}{*}{0,4149} \\
\hline & t-Stat & $-0,385$ & 0,800 & $2,538^{* *}$ & $3,517^{*}$ & $3,114^{*}$ & $-2,559^{* *}$ & \\
\hline \multirow{2}{*}{ SA } & Coeff. & $-0,032$ & 0,509 & 0,578 & 0,291 & $-0,064$ & 0,371 & \multirow{2}{*}{0,3090} \\
\hline & t-Stat & $-2,536^{*}$ & $5,098^{*}$ & $3,779^{*}$ & 1,117 & $-0,350$ & $4,094^{*}$ & \\
\hline \multirow{2}{*}{ BC } & Coeff. & $-0,047$ & 0,343 & $-1,172$ & 0,456 & $-0,426$ & $-0,104$ & \multirow{2}{*}{0,4495} \\
\hline & t-Stat & $-5,828^{*}$ & 0,246 & $-4,153^{*}$ & $3,054^{*}$ & $-2,337^{* *}$ & $-0,721$ & \\
\hline \multirow{2}{*}{ BA } & Coeff. & 0,034 & 0,379 & 0,898 & $-0,005$ & $-0,324$ & $-0,139$ & \multirow{2}{*}{0,4482} \\
\hline & t-Stat & 0,934 & $8,354^{*}$ & $4,218^{*}$ & $-0,044$ & $-3,294^{*}$ & $-0,884$ & \\
\hline
\end{tabular}

Note: $*, * *, * * *$ denote statistical significance at the $1 \%, 5 \%$ and $10 \%$ levels, respectively.

Referring to Table 9 calculated for Turkey 12 portfolio FF5F regression results, both in the original model inflationary model SE and models explaining excess returns of the BC portfolio, it is seen that $\alpha$ values were significant at $1 \%$. It is seen that both the original version and the inflationary version of the FF5F model are effective in explaining 10 portfolios from 12 portfolios in explaining the returns from portfolios. Both risk-free interest rate, as well as the returns are significantly excessive market-based inflation in Turkey in 9 of 12 models. For both the original and inflated FF5F, the SMB factor was significant in 11 models, the HML factor in 10 models, and the CMA factor at $5 \%$ in 8 models. In the risk-free interest 
rate based FF5F model, the RMW factor was significant in 8 models, and in the FF5F model based on inflation, at $5 \%$ in 7 models. The original model has a factor surplus in terms of factors that are significant compared to the inflation model. Explanatory power all models of $\mathrm{R}^{2}$ is higher than in Turkey, from Malaysia, however closer to Indonesia. In the study, the average $\alpha$, average $\mathrm{R}^{2}$ and the GRS test described in the method section have been used to compare the performance of the original FF5F model based on the riskfree interest rate tested in 4 different countries and the alternative model in which the inflation rate is used, and it is presented in Table 10.

Table 10: Performance Evaluation of Models (12 Portfolio)

\begin{tabular}{|l|l|l|l|l|}
\hline & F-GRS & Prop-GRS & Avg $|\boldsymbol{\alpha}|$ & Avg R \\
\hline & Pakistan & \multicolumn{2}{|l|}{} \\
\hline 5-Factor (Rf) & 1,94 & 0,0000 & 0,6127 & 0,7823 \\
\hline 5-Factor (REnf) & 2,10 & 0,0000 & 0,5812 & 0,7811 \\
\hline & Indonesia & & 0,9116 & 0,5636 \\
\hline 5-Factor (Rf) & 1,54 & 0,0000 & 0,9376 & 0,5635 \\
\hline 5-Factor (REnf) & 1,65 & 0,0000 & & 0,3252 \\
\hline & Malaysia & & 0,8921 & 0,3251 \\
\hline 5-Factor (Rf) & 2,98 & 0,0000 & 0,9454 & \\
\hline 5-Factor (REnf) & 3,22 & 0,0000 & & 0,4936 \\
\hline & Turkey & & 0,8223 & 0,4928 \\
\hline 5-Factor (Rf) & 2,01 & 0,0000 & 0,8453 & \\
\hline 5-Factor (REnf) & 2,36 & 0,0000 &
\end{tabular}

Looking at the GRS test statistics in Table 10, it is seen that both the original FF5F model and the alternative model based on inflation are significant in $1 \%$ of all countries. From this point of view, it can be said that both models have sufficient models to explain average returns. Looking at the GRS test statistics, it is seen that the risk-free interest rate model is a more explanatory model with a slight difference from the inflation model. Looking at the average $\mathrm{R}^{2}$ values, it is seen that the explanatory power of both models is almost the same in all countries, and there is a very small difference in support of the GRS results. Looking at the average $\alpha$ values, results supporting the previous two tests are obtained. In line with this result, it can be said that the model based on risk-free interest rate has better explanatory 
power by a canvas; however, the model based on inflation could be used for clarifying average returns.

\section{Conclusion}

Financial asset pricing models are one of the important topics of finance literature, which attracts the attention of both investors and academics. Fama and French (2015) presented a five-factor model by including the investment and profitability factor in their study, as the threefactor model, which is put forward by Fama and French (1993), is insufficient to explain the returns. While the validity of the five-factor model is tested in developed countries, its validity in developing or underdeveloped countries is also an important question. It is also known that there is an interestsensitive investor group in the world. In this study, an answer is sought for the validity of the five-factor model in developing and less developed countries, and the validity of the model to be created by using the inflation rate instead of the risk-free interest rate and the comparison with the original model. When searching for the answer to this question, as countries that might have sensitive investors to interest, Pakistan, Malaysia, Indonesia and Turkey have been selected.

First of all, in the study, country-based portfolios have been created according to the FF5F model, and crossover portfolios to be used in factor calculations were created. 12 portfolios are obtained to be used in $2 \times 2$ factor formation. When looked average excess return in terms of countries BA portfolio for Indonesia, SH portfolio for Malaysia, SL portfolio for Turkey are highest. On the other hand, the lowest excess returns are; SR portfolio for Pakistan, SH portfolio for Indonesia, Malaysia portfolio BC, and BW portfolio for Turkey. It has been observed that there are different portfolios in each country in terms of highest and lowest excess returns. In fact, it has been observed that the portfolio with the lowest return in Indonesia has the highest return in Malaysia.

As a result of the models in which each of the factors in the FF5F model is used as the dependent variable and other factors are used as independent variables; each of the factors included in the FF5F model is found to be necessary in all countries in the study. In this 4-factor analysis, it was seen that the explanatory powers of both the original model and the inflation model were close to each other. Later, it is determined that the explanatory power of the FF5F model factors in models where 12 portfolios are included as individual dependent variables are effective in all countries. In addition, it is observed that the explanatory power of the original FF5F model and the 
inflationary FF5F model are close in all countries. When we look at the GRS test, average $\alpha$ values and average $R^{2}$ values, there is evidence that the original model has little superiority over the inflation model and is very close to each other. The results of the study show parallelism with the studies of Hanif (2011), Dar and Hanif (2012), which predict that the inflation rate can be used in the CAPM model, and Çömlekçi \& Sondemir (2021), who use the inflation rate in the Fama French three-factor model. In this context, it can be argued that the inflation rate can be used in the Fama French five factor model. Investors who invest in line with Islamic principles can use the inflation rate instead of the risk-free rate of return in their asset pricing models.

It can be said that the FF5F model is also effective in developing and underdeveloped country markets and that investors with interest sensitivity can model using the inflation rate.

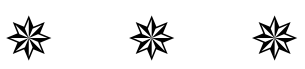

\section{Acknowledgements:}

\section{Declarations:}

\section{Ethics approval:}

Not applicable.

\section{Author contribution:}

The authors declare they have contributed equally to the article.

\section{Competing interests:}

The authors declare no competing interests.

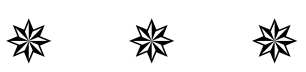

\section{REFERENCES}

ASHKER, A.A.F., (1987). Islamic business enterprise. Cengage Learning EMEA.

BANZ, R. W. (1981). The relationship between return and market value of common stocks. Journal of financial economics, 9(1), 3-18.

BASU, S. (1983). The relationship between earnings' yield, market value and return for NYSE common stocks: Further evidence. Journal of Financial Economics, 12(1), 129-156. 
BHANDARI, L. C. (1988). Debt/equity ratio and expected common stock returns: Empirical evidence. The Journal of Finance, 43(2), 507-528.

CAKICI, N. (2015). The five-factor Fama-French model: International evidence. Available at SSRN 2601662.

CARHART M. M. (1997). "On persistence in mutual fund performance", The Journal of Finance, 52/1, 57-82.

CHIAH, M., CHAI, D., ZHONG, A., \& LI, S. (2016). A better model? An empirical investigation of the Fama-French five-factor model in Australia. International Review of Finance, 16(4), 595-638.

COŞKUN, K., \& TORUN, T. (2021). Fama \& French üç ve beş faktörlü fiyatlama modellerinin geçerliliği: Borsa İstanbul örneği. İktisadi İdari ve Siyasal Araştırmalar Dergisi, 6(14), 84-102.

ÇÖMLEKÇI, İ. \& SONDEMIR, S. (2020). İslami Üç Faktör Varlık Fiyatlama Modeli: Katılım Endeksi Üzerine Bir Uygulama. Anemon Muş Alparslan Üniversitesi Sosyal Bilimler Dergisi, 8 (1). 203-211.

DAR, Abubakar Javaid, \& HANIF, Muhammad, Comparative Testing of Capital Asset Pricing Model (CAPM) and Shari'a Compliant Asset Pricing Model (SCAPM): Evidence from Karachi Stock Exchange - Pakistan, 4th South Asian International conference (SAICON-2012), Bhurban, Pakistan, 05-07 December, 2012.

De BONDT, W. F., \& THALER, R. (1985). Does the stock market overreact? The Journal of finance, 40(3), 793-805.

DICKEY, D. A. \& WAYNE A. F. (1981). Likelihood ratio statistics for autoregressive time series with a unit root, Econometrica, 49(4), 10571072.

ERDINÇ, Y. (2018). Comparison of CAPM, Three-Factor Fama-French Model and Five-Factor Fama-French Model for the Turkish Stock Market. MANAGEMENT FROM AN EMERGING MARKET PERSPECTIVE, 69.

FAMA, E. F., \& FRENCH, K. R. (1992). The cross-section of expected stock returns. the Journal of Finance, 47(2), 427-465.

FAMA, E. F., \& FRENCH, K. R. (1993). Common risk factors in the returns on stocks and bonds. Journal of financial economics, 33(1), 3-56.

FAMA, E. F., \& FRENCH, K. R. (1995). Size and book-to-market factors in earnings and returns. The journal of finance, 50(1), 131-155.

FAMA, E. F., \& FRENCH, K. R. (2015). A five-factor asset pricing model. Journal 
Nevin ÖZER, Mehmet Akif ÖNCÜ \& Ali ÖZER

of financial economics, 116(1), 1-22.

FAMA, E., \& K. R. FRENCH, (1993), "Common Risk Factors in The Returns on Stocks and Bonds", Journal of Financial Economics 33, no. 1: 3-56.

FAMA, Eugene. F. \& FRENCH, Kenneth, R. (2015). “A Five-Factor Asset Pricing Model". Journal of Financial Economics, 116, 1-22.

HANIF, Muhammad (2011), Risk and return under Shari'a frame work: An attempt to develop Shari'a compliant asset pricing model (SCAPM), Pakistan Journal of Commerce and Social Sciences (PJCSS), Vol. 5, Iss. 2, pp. 283-292.

HEANEY, R., KOH, S. \& LAN, Y. (2016). Australian Firm Characteristics and The Cross Section Variation in Equity Returns. Pacific-Basin Finance Journal, 37, 104-115.

ICD -Islamic Corporation For the Development of the Private Sector (2020), Islamic Finance Development Report, https://icdps.org/uploads/files/ICD-

Refinitiv\%20IFDI\%20Report\%2020201607502893_2100.pdf

LINTNER, J. (1965). "The valuation of risk assets and the selection of risky investments in stock portfolios and capital budgets", There view of economics and statistics, 13- 37.

MERTON, R. C. (1973). An intertemporal capital asset pricing model. Econometrica: Journal of the Econometric Society, 867-887.

MOSSIN, J. (1966). "Equilibrium in a capital asset market", Econometrica: Journal of the econometric society, 768-783.

PHILLIPS, P., \& PERRON P., (1988). Testing for a unit root in time series regression, Biometrica, 75, 335-46.

ROSENBERG, B., REID, K., \& LANSTEIN, R. (1985). Persuasive evidence of market inefficiency. The Journal of Portfolio Management, 11(3), 9-16.

ROSS, S. A. (1976). Options and efficiency. The Quarterly Journal of Economics, 90(1), 75-89.

SHAIKH, S. (2010). Corporate Finance in an Interest free economy: An alternate approach to practiced Islamic Corporate finance. Munich Personal RePEc Archive (MPRA), Paper No. 19459.

SHARPE W. (1964). "Capital Asset Prices - A Theory of Market Equilibrium Under Conditions of Risk", Journal of Finance, Vol: 19, ss. 425-442.

STOLL, H. R., \& WHALEY, R. E. (1990). The Dynamics of Stock Index and Stock Index Futures Returns. Journal of Financial and Quantitative analysis, 
441-468.

TOMKINS, C., \& 'Abdul Karim, R. A. (1987). The Shari'ah and its Implications for Islamic Financial Analysis: An Opportunity to Study Interactions Among Society, Organization, and Accounting. American Journal of Islam and Society, 4(1), 101-115.

YANG, Q., LI, L., ZHU, Q., \& MIZRACH, B. (2017). Analysis of US Sector of Services with a New Fama-French 5-Factor Model.Applied Mathematics, 8(9), 1307-1319.

YÜCEL, A. G., \& KÖSEOĞLU, A. (2020). Do participation banks contribute to economic growth? Time-series evidence from Turkey. Bilimname, 2020(42), 155-180.

ZHOU, W., \& LI, L. (2016). A New Fama-French 5-Factor Model Based on SSAEPD Error and GARCH-Type Volatility. Journal of Mathematical Finance, 6(5), 711-727.

资资 


\title{
FAMA FRENCH 5 FAKTÖR MODELİNE KARŞI ALTERNATİF FAMA FRENCH 5 FAKTÖR MODELİ: SEÇİLMİŞ İSLAM ÜLKELERİ UYGULAMASI
}

\author{
Nevin ÖZERa \\ Mehmet Akif ÖNCÜb \\ (D) Ali ÖZERc \\ İstemi ÇÖMLEKÇCid
}

\section{Extended Abstract}

Sharpe (1964), Lintner (1965) ve Mossin (1966) tarafından ileri sürülen finansal varlık fiyatlama modeli (CAPM), Carhart (1997) tarafindan sunulan 4 faktör varlık fiyatlama modeli, Fama - French (1993 ve 2015) tarafından ortaya konan 3 faktör varlık fiyatlama modeli ve 5 faktör varlık fiyatlama modeli risksiz getiri oranı temel alınarak geliștirilmiştir. Literatürde risksiz getiri oranı olarak ise faiz getirili bir finansal varlık olan devlet tahvillerinin ele alındığı görülmektedir. Bu kapsamda varlık fiyatlandırma modellerinin faizsizlik prensibi ile hareket etmeyi planlayan İslami finansal varlık yatırımcıları tarafından uygulanması mümkün olmamakla beraber, faizsiz bir finansal varlık fiyatlama modelinin geliştirilmesini kaçınılmaz kılmıştır.

Faizsiz bir finansal varlık fiyatlama modeli geliştirilmesi ile ilgili olarak farklı modeller geliştirilmiştir. Tomkins ve Karim (1987) CAPM modelinde risksiz getiri oranına yer vermedikleri bir model önerirken Ashker (1987) ise risksiz getiri oranı yerine zekat oranının ( zekat oranı / (1- zekat oranı)) kullanılabileceğini ileri sürmüştür. Shaikh (2009) risksiz getiri oranı yerine Nominal gayri safi yurtiçi hasılanın kullanılabileceğini ileri sürmüştür. Hanif ise risksiz getiri oranı yerine enflasyon oranını, Tüketici Fiyat Endeksini (TÜFE), toptan eşya fiyat endeksini (TEFE) veya seçilmiş malların yadapara

a Asst. Prof., Düzce Universitesi, nevinozer@duzce.edu.tr

b Prof., Düzce Universitesi, mehmetakifoncu@duzce.edu.tr

c Assoc. Prof., Düzce Universitesi, aliozer@duzce.edu.tr

d Assoc. Prof., Düzce Universitesi, istemicomlekci@duzce.edu.tr 
birimlerinin oluşturduğu bir sepeti baz alanİslami Finansal varlık fiyatlama modellerinin kurulabileceğini savunmuştur.

Bu çalışmada, 2012-2020 yıllarında İslam ülkelerinde Fama-French 5 faktör modelinin risksiz faiz oranıla olan orijinal modeli ile faiz oranı yerine enflasyon oranı kullanılarak oluşturulan Fama-French 5 faktör modeli karşılaştırmalı olarak analiz edilmiştir. İslami ülkeleri olarak Endonezya, Malezya, Türkiye ve Pakistan çalışmaya dahil edilmiştir. Çalışmada Malezya için Kuala Lumpur Bileşik Endeksi (KLCI), Endenozya için Jakarta İslami Endeksi (JKII), Pakistan için Karachi Meezan Endeksi (KMI) ve Türkiye için ise Katılım Endeksi (KATLM) çalışma için seçilmiş ve endeksteki en büyük 30 firma üzerinden analiz gerçekleștirilmiştir. Çalışmaya dahil edilen firmalara ait veriler Thomson Reuters Eikon veritabanından elde edilmiștir.

Çalışmada, modelin test edilebilmesi için gerekli olan faktörler SMB (Büyüklük Faktörü), HML (Değer Faktörü, DD/PD Oranı), RMW (Karlılık Faktörü) ve CMA (Yatırım Faktörü) olarak modelin 4 faktörü ve Pazar Primi faktörü olan $(R m-R \mathrm{i})$ ve bu çalışmada risksiz faiz oranı yerine kullanılan enflasyon oranı $(R m-R$ inf $)$ faktörleridir. Çalışmada kullanılan ülkeler ve ülkelerden seçilmiş olan hisse senetleri için ayrı ayrı veri seti oluşturulmuş ve daha sonra faktör ve portföylerin oluşumu için birleștirilmiştir. Büyüklük faktörü, her bir firmanın t yılının haziran ayı sonundaki piyasa değerleri hesaplanarak elde edilmiştir. Haziran ayı piyasa değeri hesaplandıktan sonra firmalar büyük ve küçük olarak iki gruba ayrılmıştır. Porföyler her yıl, t yllının Temmuz ayından t+1 yılının Haziran ayı sonu için yeniden hesaplanmış ve güncellenmiştir. Değer faktörü hesaplanırken Defter Değeri/Piyasa Değeri oranı kullanılmıştır. Defter Değeri/Piyasa değeri hesaplanırken Haziran ayındaki hisse senedinin fiyatı ile t-1 yılı dönem sonundaki ödenmiş sermaye değeri dikkate alınarak hesaplanmıştır. Daha sonra elde edilen sonuçlar büyükten küçüğe doğru sıralanmıştır. Daha sonra firmalar B/M değerlerine göre alt $\% 30$, orta $\% 40$ ve üst $\% 30$ şeklinde üç gruba ayrılmıştır. Bu gruplar yüksek, orta ve düşük olarak isimlendirilmiştir. $\mathrm{Bu}$ faktör için de portföyler yıllık olarak güncellenmiştir. Karlılık faktörü oluşturulurken, faaliyet karlılığının t-1 dönem sonu değerinin, t-1 yılı öz kaynak değerine bölünmesiyle elde edilmiştir. Yatırım faktörünün oluşturulmasında, toplam aktiflerin t-1 yılı ile t-2 yll arasındaki fark alınarak, t-2 yılına oranlanmıştır. Karlılık ve yatırım faktörleri, değer faktöründe olduğu gibi büyükten küçüğe doğru sıralanmış ve üç gruba ayrılmıştır.

Çalışmada oluşturulan portföy getirileri ülkeler açısından incelendiğinde, 
Pakistan'da büyük ve karlılığı güçlü firmaların oluşturduğu portföyün aylık aşırı getirisi en fazla iken, ikinci sırada küçük ve yatırım açısından tutumlu firmalar yer almaktadır. En düşük aşırı getiri ise küçük ve karlılığı güçlü firmalarda görülmektedir. Endonezya'ya bakıldığında, en yüksek aşırı getirinin büyük ve yatırım açısından agresif firmalarda olduğu, ikinci sırada ise küçük ve yatırım açısından agresif firmalarda olduğu görülmüştür. Endonezya'da agresif yatırım anlayışına sahip firmaların pazar getirisini aşan ortalama getirisinin en yüksek olduğu söylenebilir. En düşük getiriye sahip portföy ise küçük ve $\mathrm{B} / \mathrm{M}$ oranı yüksek firmalarda görülmüştür. Malezya'da en yüksek aşırı getiriye küçük ve B/M oranı yüksek firmalar sahipken, ikinci sırada büyük ve karlılığı güçlü firmalar bulunmaktadır. En düşük getirisi ise büyük ve yatırım açısından tutucu firmalarda görülmüştür. Son olarak Türkiye'ye bakıldığında en yüksek aşırı getirinin küçük ve B/M oranı düşük firmalarda, ikinci sırada ise küçük ve $B / M$ oranı yüksek firmalarda olduğu görülmektedir. Türkiye'de piyasa değeri küçük firmaların daha yüksek aşırı getiriye sahip olduğu söylenebilir. Diğer taraftan en düşük aşırı getiri ise büyük ve karlılığı zayıf firmalarda olduğu görülmektedir. Ülkelerde en yüksek aşırı getiri açısından farklı portföylerin etkin olduğu görülmektedir. Hatta bir ülkede en yüksek aşırı getiriye sahip olan portföyün, diğer ülkede en düşük getiriye sahip olduğu görülmüştür. Sadece küçük firmaların aşırı getirisinin, büyük firmalardan fazla olduğu söylenebilir. Aşırı getirilerin dalgalanmasına bakıldığında Pakistan ve Endonezya piyasalarının riskli olduğu, Malezya'nın ise en az riskli olduğu görülmektedir.

FF5F modelinde yer alan faktörlerin her birinin bağımlı değişken olarak kullanıldığı ve diğer faktörlerin bağımsız değişken olarak kullanıldığı modeller sonucunda; FF5F modelinde yer alan faktörlerin her birinin çalışmadaki bütün ülkelerde gerekli olduğu görülmüştür. Yapılan 4 faktörlü bu analizde hem orijinal modelin hem de enflasyonlu modelin açıklama güçlerinin birbirine yakın olduğu görülmüştür. Daha sonra 12 portföyün tek tek bağımlı değişken olarak yer aldığı modellerde FF5F modeli faktörlerinin açıklama gücünün bütün ülkelerde etkin olduğu tespit edilmiştir. Ayrıca bütün ülkelerde orijinal FF5F modeli ile enflasyonlu FF5F modelin açıklama güçlerinin yakın olduğu görülmüștür. Yapılan GRS testi, ortalama $\alpha$ değerleri ve ortalama $\mathrm{R}^{2}$ değerleri açısından bakıldığında orijinal modelin enflasyonlu modelden küçük üstünlüğünün bulunduğu ve birbirilerine çok yakın olduğuna dair kanıtlar elde edilmiştir. FF5F modelinin gelişmekte olan ve az gelişmiş ülke piyasalarında da etkin olduğu ve faiz hassasiyeti olan yatırımcların enflasyon oranını kullanarak modelleme yapabileceğ söylenebilir. 
Anahtar Kelimeler: Finans, CAPM, Fama-French 5 Faktör, Faiz, Enflasyon

\section{Ekler:}

\section{Table 5a) PAKİSTAN}

\begin{tabular}{|c|c|c|c|c|c|}
\hline \multicolumn{6}{|c|}{ PAKİSTAN } \\
\hline & RmRf & SMB & HML & RMW & CMA \\
\hline Int. & $\begin{array}{l}0,144066 \\
(0,8080)\end{array}$ & $\begin{array}{l}0,21530 \\
(2,3421)^{* *}\end{array}$ & $\begin{array}{l}-0,10265 \\
(-0,6762)\end{array}$ & $\begin{array}{l}-0,11358 \\
(-0,84364)\end{array}$ & $\begin{array}{l}-0,16424 \\
(-1,1459)\end{array}$ \\
\hline RmRf & - & $\begin{array}{l}0,08205 \\
(1,71059)^{* * *}\end{array}$ & $\begin{array}{l}-0,13931 \\
(-1,73021)^{* *}\end{array}$ & $\begin{array}{l}-0,41151 \\
(-5,30912)^{*}\end{array}$ & $\begin{array}{l}0,157564 \\
(2,07546)^{* *}\end{array}$ \\
\hline SMB & $\begin{array}{l}0,38375 \\
(1,71059)^{* * *}\end{array}$ & - & $\begin{array}{l}1,02389 \\
(7,29912)^{*}\end{array}$ & $\begin{array}{l}0,330575 \\
(1,75003)^{* * *}\end{array}$ & $\begin{array}{l}0,303388 \\
(1,83882)^{* * *}\end{array}$ \\
\hline HML & $\begin{array}{l}-0,23108 \\
(-1,7302)^{* * *}\end{array}$ & $\begin{array}{l}0,36317 \\
(7,29912)^{*}\end{array}$ & - & $\begin{array}{l}-0,10755 \\
(-0,94475)\end{array}$ & $\begin{array}{l}-0,35124 \\
(-3,77708)^{*}\end{array}$ \\
\hline RMW & $\begin{array}{l}-0,5795 \\
(-5,30911)^{*}\end{array}$ & $\begin{array}{l}0,099552 \\
(1,75006)^{* *}\end{array}$ & $\begin{array}{l}-0,09131 \\
(-0,94475)\end{array}$ & - & $\begin{array}{l}0,193881 \\
(2,15582)^{* *}\end{array}$ \\
\hline CMA & $\begin{array}{l}0,28988 \\
(2,07546)^{*}\end{array}$ & $\begin{array}{l}0,11935 \\
(1,83882)^{* *}\end{array}$ & $\begin{array}{l}-0,38955 \\
(-3,77708)^{*}\end{array}$ & $\begin{array}{l}0,253267 \\
(2,15582)^{* *}\end{array}$ & - \\
\hline \multirow[t]{2}{*}{$\mathbf{R}^{2}$} & 0,287 & 0,387 & 0,459 & 0,269 & 0,237 \\
\hline & RmInf & SMB & HML & RMW & CMA \\
\hline Int. & $\begin{array}{l}0,142885 \\
(0,57350)\end{array}$ & $\begin{array}{l}0,215419 \\
(2,39638)^{* *}\end{array}$ & $\begin{array}{l}-0,102819 \\
(-0,721976)\end{array}$ & $\begin{array}{l}-0,114087 \\
(-0,965308)\end{array}$ & $\begin{array}{l}-0,164050 \\
(-1,097127)\end{array}$ \\
\hline RmInf & - & $\begin{array}{l}0,080324 \\
(1,671882)^{* * *}\end{array}$ & $\begin{array}{l}-0,137147 \\
(-1,701306)^{* * *}\end{array}$ & $\begin{array}{l}-0,409785 \\
(-5,265447)^{*}\end{array}$ & $\begin{array}{l}0,157889 \\
(2,079821)^{* *}\end{array}$ \\
\hline SMB & $\begin{array}{l}0,375009 \\
(1,67188)^{* * *}\end{array}$ & - & $\begin{array}{l}1,022900 \\
(7,289868)^{*}\end{array}$ & $\begin{array}{l}0,327009 \\
(1,72829)^{* * *}\end{array}$ & $\begin{array}{l}0,304574 \\
(1,847818)^{* * *}\end{array}$ \\
\hline HML & $\begin{array}{l}-0,227190 \\
(-1,7013)^{* * *}\end{array}$ & $\begin{array}{l}0,362943 \\
(7,289868)^{*}\end{array}$ & - & $\begin{array}{l}-0,105601 \\
(-0,926172)\end{array}$ & $\begin{array}{l}-0,351703 \\
(-3,785644)^{*}\end{array}$ \\
\hline RMW & $\begin{array}{l}-0,574706 \\
(-5,26544)^{*}\end{array}$ & $\begin{array}{l}0,098232 \\
(1,728293)^{* * *}\end{array}$ & $\begin{array}{l}-0,089403 \\
(-0,926172)\end{array}$ & - & $\begin{array}{l}0,193283 \\
(2,153472)^{* *}\end{array}$ \\
\hline CMA & $\begin{array}{l}0,290449 \\
(2,07981)^{* *}\end{array}$ & $\begin{array}{l}0,120008 \\
(1,847818)^{* *}\end{array}$ & $\begin{array}{l}-0,390562 \\
(-3,785644)^{*}\end{array}$ & $\begin{array}{l}0,253525 \\
(2,153472)^{* *}\end{array}$ & - \\
\hline $\mathbf{R}^{2}$ & 0,283 & 0,385 & 0,458 & 0,266 & 0,237 \\
\hline
\end{tabular}


Nevin ÖZER, Mehmet Akif ÖNCÜ \& Ali ÖZER

Tablo 5b) ENDONEZYA

\begin{tabular}{|c|c|c|c|c|c|}
\hline \multicolumn{6}{|c|}{ ENDONEZYA } \\
\hline & RmRf & SMB & HML & RMW & CMA \\
\hline Int. & $\begin{array}{l}-0,053438 \\
(-0,810173)\end{array}$ & $\begin{array}{l}0,05907 \\
(0,347333)\end{array}$ & $\begin{array}{l}-0,08459 \\
(-0,093253)\end{array}$ & $\begin{array}{l}-0,03551 \\
(-0,134583)\end{array}$ & $\begin{array}{l}0,101148 \\
(0,478240)\end{array}$ \\
\hline RmRf & - & $\begin{array}{l}0,121643 \\
(1,929366)^{* * *}\end{array}$ & $\begin{array}{l}-0,072803 \\
(-0,601718)\end{array}$ & $\begin{array}{l}-0,012665 \\
(-0,125637)\end{array}$ & $\begin{array}{l}-0,020791 \\
(-0,351694)\end{array}$ \\
\hline SMB & $\begin{array}{l}0,323065 \\
(1,929366)^{* * *}\end{array}$ & - & $\begin{array}{l}1,473192 \\
(11,95509)^{*}\end{array}$ & $\begin{array}{l}0,462660 \\
(2,947370)^{* *}\end{array}$ & $\begin{array}{l}0,452417 \\
(5,389990)^{*}\end{array}$ \\
\hline HML & $\begin{array}{l}-0,054434 \\
(-0,601718)\end{array}$ & $\begin{array}{l}0,414735 \\
(11,95509)^{*}\end{array}$ & - & $\begin{array}{l}-0,305611 \\
(-3,769597)^{*}\end{array}$ & $\begin{array}{l}-0,168118 \\
(-3,500899)^{*}\end{array}$ \\
\hline RMW & $\begin{array}{l}-0,013693 \\
(-0,125637)\end{array}$ & $\begin{array}{l}0,188352 \\
(2,947370)^{*}\end{array}$ & $\begin{array}{l}-0,441941 \\
(-3,769597)^{*}\end{array}$ & - & $\begin{array}{l}0,013382 \\
(0,217601)\end{array}$ \\
\hline CMA & $\begin{array}{l}-0,065285 \\
(-0,351694)\end{array}$ & $\begin{array}{l}0,534894 \\
(5,389990)^{*}\end{array}$ & $\begin{array}{l}-0,706040 \\
(-3,500899)^{*}\end{array}$ & $\begin{array}{l}0,038863 \\
(0,217601)\end{array}$ & - \\
\hline \multirow[t]{2}{*}{$\mathbf{R}^{2}$} & 0,068 & 0,691 & 0,639 & 0,167 & 0,279 \\
\hline & RmInf & SMB & HML & RMW & CMA \\
\hline Int. & $\begin{array}{l}-0,051513 \\
(-0,356329)\end{array}$ & $\begin{array}{l}0,06673 \\
(0,258374)\end{array}$ & $\begin{array}{l}-0,08321 \\
(-0,065314)\end{array}$ & $\begin{array}{l}-0,03530 \\
(-0,129784)\end{array}$ & $\begin{array}{l}0,101188 \\
(0,496658)\end{array}$ \\
\hline RmInf & - & $\begin{array}{l}0,121716 \\
(1,931806)^{* * *}\end{array}$ & $\begin{array}{l}-0,073884 \\
(-0,611064)\end{array}$ & $\begin{array}{l}-0,014786 \\
(-0,146770)\end{array}$ & $\begin{array}{l}-0,020402 \\
(-0,345283)\end{array}$ \\
\hline SMB & $\begin{array}{l}0,323656 \\
(1,931806)^{* * *}\end{array}$ & - & $\begin{array}{l}1,473405 \\
(11,95990)^{*}\end{array}$ & $\begin{array}{l}0,463325 \\
(2,951953)^{*}\end{array}$ & $\begin{array}{l}0,452325 \\
(5,388018)^{*}\end{array}$ \\
\hline HML & $\begin{array}{l}-0,055310 \\
(-0,611064)\end{array}$ & $\begin{array}{l}0,414806 \\
(11,95990)^{*}\end{array}$ & - & $\begin{array}{l}-0,305720 \\
(-3,771021)^{*}\end{array}$ & $\begin{array}{l}-0,168122 \\
(-3,500670)^{*}\end{array}$ \\
\hline RMW & $\begin{array}{l}-0,016006 \\
(-0,146770)\end{array}$ & $\begin{array}{l}0,188615 \\
(2,951953)^{*}\end{array}$ & $\begin{array}{l}-0,442072 \\
(-3,771021)^{*}\end{array}$ & - & $\begin{array}{l}0,013341 \\
(0,216919)\end{array}$ \\
\hline CMA & $\begin{array}{l}-0,064131 \\
(-0,345283)\end{array}$ & $\begin{array}{l}0,534705 \\
(5,388018)^{*}\end{array}$ & $\begin{array}{l}-0,705939 \\
(-3,500670)^{*}\end{array}$ & $\begin{array}{l}0,038739 \\
(0,216919)\end{array}$ & - \\
\hline $\mathbf{R}^{2}$ & 0,068 & 0,691 & 0,639 & 0,167 & 0,279 \\
\hline
\end{tabular}


Tablo 5c) MALEZYA

\begin{tabular}{|c|c|c|c|c|c|}
\hline \multicolumn{6}{|c|}{ MALEZYA } \\
\hline & RmRf & SMB & HML & RMW & CMA \\
\hline Int. & $\begin{array}{l}-0,051846 \\
(-0,737879)\end{array}$ & $\begin{array}{l}-0,02456 \\
(-0,081591)\end{array}$ & $\begin{array}{l}-0,05174 \\
(-0,093525)\end{array}$ & $\begin{array}{l}-0,03096 \\
(-1,602795)\end{array}$ & $\begin{array}{l}0,10684 \\
(0,337300)\end{array}$ \\
\hline RmRf & - & $\begin{array}{l}0,060455 \\
(1,201556)\end{array}$ & $\begin{array}{l}-0,019283 \\
(-0,248301)\end{array}$ & $\begin{array}{l}-0,091124 \\
(-1,121479)\end{array}$ & $\begin{array}{l}0,254070 \\
(3,159817)^{*}\end{array}$ \\
\hline SMB & $\begin{array}{l}0,258333 \\
(1,201556)\end{array}$ & - & $\begin{array}{l}0,903960 \\
(6,972248)^{*}\end{array}$ & $\begin{array}{l}0,632735 \\
(4,067159)^{*}\end{array}$ & $\begin{array}{l}-0,061140 \\
(-0,349418)\end{array}$ \\
\hline HML & $\begin{array}{l}-0,035111 \\
(-0,248301)\end{array}$ & $\begin{array}{l}0,385188 \\
(6,972248)^{*}\end{array}$ & - & $\begin{array}{l}-0,042647 \\
(-0,386617)\end{array}$ & $\begin{array}{l}0,044123 \\
(0,386357)\end{array}$ \\
\hline RMW & $\begin{array}{l}-0,149605 \\
(-1,121479)\end{array}$ & $\begin{array}{l}0,243099 \\
(4,067159)^{*}\end{array}$ & $\begin{array}{l}-0,038452 \\
(-0,386617)\end{array}$ & - & $\begin{array}{l}0,019516 \\
(0,179855)\end{array}$ \\
\hline CMA & $\begin{array}{l}0,389149 \\
(3,159817)^{*}\end{array}$ & $\begin{array}{l}-0,021915 \\
(-0,349418)\end{array}$ & $\begin{array}{l}0,037116 \\
(0,386357)\end{array}$ & $\begin{array}{l}0,018208 \\
(0,179855)\end{array}$ & - \\
\hline \multirow[t]{2}{*}{$\mathbf{R}^{2}$} & 0,119 & 0,488 & 0,393 & 0,212 & 0,100 \\
\hline & RmInf & SMB & HML & RMW & CMA \\
\hline Int. & $\begin{array}{l}-0,041081 \\
(-0,432656)\end{array}$ & $\begin{array}{l}-0,034146 \\
(-0,120234)\end{array}$ & $\begin{array}{l}-0,05157 \\
(-0,084833)\end{array}$ & $\begin{array}{l}-0,03026 \\
(-1,568870)\end{array}$ & $\begin{array}{l}0,09486 \\
(0,239741)\end{array}$ \\
\hline RmInf & - & $\begin{array}{l}0,060148 \\
(1,193560)\end{array}$ & $\begin{array}{l}-0,017691 \\
(-0,227458)\end{array}$ & $\begin{array}{l}-0,091073 \\
(-1,119235)\end{array}$ & $\begin{array}{l}0,250386 \\
(3,097749)^{*}\end{array}$ \\
\hline SMB & $\begin{array}{l}0,256260 \\
(1,193560)\end{array}$ & - & $\begin{array}{l}0,903610 \\
(6,968631)^{*}\end{array}$ & $\begin{array}{l}0,632566 \\
(4,066242)^{*}\end{array}$ & $\begin{array}{l}-0,059652 \\
(-0,340282)\end{array}$ \\
\hline HML & $\begin{array}{l}-0,032120 \\
(-0,227458)\end{array}$ & $\begin{array}{l}0,385077 \\
(6,968631)^{*}\end{array}$ & - & $\begin{array}{l}-0,042375 \\
(-0,384156)\end{array}$ & $\begin{array}{l}0,043381 \\
(0,379133)\end{array}$ \\
\hline RMW & $\begin{array}{l}-0,149099 \\
(-1,119235)\end{array}$ & $\begin{array}{l}0,243071 \\
(4,066242)^{*}\end{array}$ & $\begin{array}{l}-0,038209 \\
(-0,384156)\end{array}$ & - & $\begin{array}{l}0,018767 \\
(0,172622)\end{array}$ \\
\hline CMA & $\begin{array}{l}0,380979 \\
(3,097749)^{*}\end{array}$ & $\begin{array}{l}-0,021304 \\
(-0,340282)\end{array}$ & $\begin{array}{l}0,036355 \\
(0,379133)\end{array}$ & $\begin{array}{l}0,017442 \\
(0,172622)\end{array}$ & - \\
\hline $\mathbf{R}^{2}$ & 0,116 & 0,488 & 0,393 & 0,212 & 0,097 \\
\hline
\end{tabular}


Nevin ÖZER, Mehmet Akif ÖNCÜ \& Ali ÖZER

Table 5d) TÜRKIYE

\begin{tabular}{|c|c|c|c|c|c|}
\hline \multicolumn{6}{|c|}{ TÜRKIYYE } \\
\hline & RmRf & SMB & HML & RMW & CMA \\
\hline Int. & $\begin{array}{l}-0,04656 \\
(-0,739989)\end{array}$ & $\begin{array}{l}-0,04591 \\
(-1,9652)^{* * *}\end{array}$ & $\begin{array}{l}-0,08523 \\
(-1,7056)^{* * *}\end{array}$ & $\begin{array}{l}-0,06509 \\
(-1,408220)\end{array}$ & $\begin{array}{l}-0,08256 \\
(-3,530832)^{*}\end{array}$ \\
\hline RmRf & - & $\begin{array}{l}-0,027014 \\
(-0,683502)\end{array}$ & $\begin{array}{l}-0,023635 \\
(-0,432965)\end{array}$ & $\begin{array}{l}-0,008214 \\
(-0,105837)\end{array}$ & $\begin{array}{l}-0,011550 \\
(-0,278985)\end{array}$ \\
\hline SMB & $\begin{array}{l}-0,189074 \\
(-0,683502)\end{array}$ & - & $\begin{array}{l}0,402661 \\
(2,912099)^{*}\end{array}$ & $\begin{array}{l}-0,203211 \\
(-0,995060)\end{array}$ & $\begin{array}{l}-0,067850 \\
(-0,620497)\end{array}$ \\
\hline HML & $\begin{array}{l}-0,086978 \\
(-0,432965)\end{array}$ & $\begin{array}{l}0,211707 \\
(2,912099)^{*}\end{array}$ & - & $\begin{array}{l}-0,198706 \\
(-1,347902)\end{array}$ & $\begin{array}{l}-0,168970 \\
(-2,18149)^{* *}\end{array}$ \\
\hline RMW & $\begin{array}{l}-0,014985 \\
(-0,105837)\end{array}$ & $\begin{array}{l}-0,052968 \\
(-0,995060)\end{array}$ & $\begin{array}{l}-0,098510 \\
(-1,347902)\end{array}$ & - & $\begin{array}{l}0,148036 \\
(2,754214)^{*}\end{array}$ \\
\hline CMA & $\begin{array}{l}-0,073987 \\
(-0,278985)\end{array}$ & $\begin{array}{l}-0,062095 \\
(-0,620497)\end{array}$ & $\begin{array}{l}-0,294118 \\
(-2,18149)^{* *}\end{array}$ & $\begin{array}{l}0,519772 \\
(2,754214)^{*}\end{array}$ & - \\
\hline $\mathbf{R}^{2}$ & 0,009 & 0,149 & 0,210 & 0,158 & 0,181 \\
\hline & RmInf & SMB & HML & RMW & CMA \\
\hline Int. & $\begin{array}{l}0,01163 \\
(0,184309)\end{array}$ & $\begin{array}{l}-0,04432 \\
(-1,9002)^{* * *}\end{array}$ & $\begin{array}{l}-0,08391 \\
(-1,6681)^{* * *}\end{array}$ & $\begin{array}{l}-0,06459 \\
(-1,401370)\end{array}$ & $\begin{array}{l}-0,08190 \\
(-3,509610)^{*}\end{array}$ \\
\hline RmInf & - & $\begin{array}{l}-0,027652 \\
(-0,701873)\end{array}$ & $\begin{array}{l}-0,020906 \\
(-0,383905)\end{array}$ & $\begin{array}{l}-0,009312 \\
(-0,120337)\end{array}$ & $\begin{array}{l}-0,011287 \\
(-0,273393)\end{array}$ \\
\hline SMB & $\begin{array}{l}-0,194718 \\
(-0,701873)\end{array}$ & - & $\begin{array}{l}0,403239 \\
(2,915518)^{*}\end{array}$ & $\begin{array}{l}-0,203464 \\
(-0,996190)\end{array}$ & $\begin{array}{l}-0,067866 \\
(-0,620547)\end{array}$ \\
\hline HML & $\begin{array}{l}-0,077345 \\
(-0,383905)\end{array}$ & $\begin{array}{l}0,211858 \\
(2,915518)^{*}\end{array}$ & - & $\begin{array}{l}-0,198704 \\
(-1,348220)\end{array}$ & $\begin{array}{l}-0,168844 \\
(-2,18025)^{* *}\end{array}$ \\
\hline RMW & $\begin{array}{l}-0,017087 \\
(-0,120337)\end{array}$ & $\begin{array}{l}-0,053021 \\
(-0,996190)\end{array}$ & $\begin{array}{l}-0,098556 \\
(-1,348220)\end{array}$ & - & $\begin{array}{l}0,148022 \\
(2,753812)^{*}\end{array}$ \\
\hline CMA & $\begin{array}{l}-0,072713 \\
(-0,273393)\end{array}$ & $\begin{array}{l}-0,062090 \\
(-0,620547)\end{array}$ & $\begin{array}{l}-0,294018 \\
(-2,18025)^{* *}\end{array}$ & $\begin{array}{l}0,519684 \\
(2,753812)^{*}\end{array}$ & - \\
\hline $\mathbf{R}^{2}$ & 0,009 & 0,149 & 0,209 & 0,158 & 0,181 \\
\hline
\end{tabular}

Teşekkür: 


\section{Beyanname:}

\section{Etik Kurul İzni:}

Etik Kurul İzni gerekmemektedir.

\section{Katkı Oranı Beyanı:}

Yazarlar, makaleye eşit oranda katkı sağlamış olduklarını beyan etmektedirler.

\section{3. Çıkar Çatışması Beyanı:}

Yazarlar, herhangi bir çıkar çatışması olmadığını beyan etmektedirler.

䊏的 